\title{
Renal Cell Tumors: Uncovering the Biomarker Potential of ncRNAs
}

\author{
Gonçalo Outeiro-Pinho ${ }^{1,+}+\mathbb{C}$, Daniela Barros-Silva ${ }^{1,+}{ }^{\dagger}$, Margareta P. Correia ${ }^{1} \mathbb{C}$, \\ Rui Henrique ${ }^{1,2,3}$ (D) and Carmen Jerónimo $1,3, * \mathbb{C}$ \\ 1 Cancer Biology and Epigenetics Group, IPO Porto Research Center (CI-IPOP), Portuguese Oncology \\ Institute of Porto (IPO Porto), Rua Dr. António Bernardino de Almeida, 4200-072 Porto, Portugal; \\ goncalo.outeiro.pinho@ipoporto.min-saude.pt (G.O.-P.); daniela.silva@ipoporto.min-saude.pt (D.B.-S.); \\ margareta.correia@ipoporto.min-saude.pt (M.P.C.); henrique@ipoporto.min-saude.pt (R.H.)

Received: 29 June 2020; Accepted: 5 August 2020; Published: 7 August 2020

\begin{abstract}
Renal cell tumors (RCT) remain as one of the most common and lethal urological tumors worldwide. Discrimination between (1) benign and malignant disease, (2) indolent and aggressive tumors, and (3) patient responsiveness to a specific therapy is of major clinical importance, allowing for a more efficient patient management. Nonetheless, currently available tools provide limited information and novel strategies are needed. Over the years, a putative role of non-coding RNAs (ncRNAs) as disease biomarkers has gained relevance and is now one of the most prolific fields in biological sciences. Herein, we extensively sought the most significant reports on ncRNAs as potential RCTs' diagnostic, prognostic, predictive, and monitoring biomarkers. We could conclude that ncRNAs, either alone or in combination with currently used clinical and pathological parameters, might represent key elements to improve patient management, potentiating the implementation of precision medicine. Nevertheless, most ncRNA biomarkers require large-scale validation studies, prior to clinical implementation.
\end{abstract}

Keywords: Renal cell tumors; renal cell carcinoma; biomarkers; liquid biopsies; diagnosis; prognosis; non-coding RNAs; miRNA; lncRNA

\section{Renal Cell Tumors}

Renal cell tumors (RCT) rank 16th among the most common neoplasms in adults, representing more than 400,000 new cases yearly ( $2.2 \%$ of all cancer diagnosis) in both genders, with a mortality rate of 2.4/100,000, worldwide [1]. RCTs are a heterogenous group of tumors, spanning from benign to overtly malignant behavior and being highly diverse at the molecular, genomic/epigenomic, morphological, and clinical level [2]. Benign renal tumors correspond to $10-13 \%$ of all RCT, being oncocytomas the most prevalent, whereas clear cell renal cell carcinomas (ccRCC) are the most common and one of the most aggressive malignant RCT subtypes (70-75\% of all cases), followed by papillary renal cell carcinomas (pRCC, 10-15\%) and chromophobe renal cell carcinomas (chRCC, 5-10\%) [3]. Since these four types of RCT represent the vast majority of renal tumors, they will represent the main focus of this review. Although, in recent years, mortality rate has dropped, incidence has increased, mainly due to incidental detection. Indeed, more than $50 \%$ of RCTs are incidentally detected after nonspecific musculoskeletal or gastrointestinal complaints entailing abdominal imaging [4]. Visible 
and/or palpable manifestations, such as flank pain, hematuria, and abdominal mass are infrequent, only observed in a small number of cases, and are mostly associated with advanced disease [5]. Thus, physical examination does not allow for early diagnosis of RCT. Presently, partial or radical nephrectomy is the main curative treatment available since these tumors are notably resistant to both radio- and chemotherapy [6]. However, cases of complete curative treatment have been reported with interleukin-2 (IL-2) and nivolumab-based therapy [7,8]. The clinical benefit of adjuvant interferon-alpha (IFN- $\alpha$ ) and IL-2, heat shock protein-peptide complex-96 (HSPPC-96, Vitespen ${ }^{\circledR}$ ), girentuximab, or vascular endothelial growth factor receptor/tyrosine kinase inhibitor (VEGFR/TKI) for high-risk RCT patients remains unclear, as results of published randomized trials are conflicting [9-14]. Furthermore, 30 to $35 \%$ of the cases are diagnosed with locally invasive or distant disease, and 20 to $40 \%$ of the patients without metastasis at the time of diagnosis will develop metastatic dissemination during the disease course [15]. For metastatic renal cell carcinoma (mRCC), VEGFR/TKI antiangiogenic drugs, such as pazopanib, sunitinib, or cabozantinib, have been shown to improve disease control [16-18]. In patients where antiangiogenic agents are inefficient, the use of mammalian target of rapamycin (mTOR) pathway inhibitors, such as everolimus and temsirolimus, has shown favorable results [19]. Lastly, a new wave of immunotherapy-based approach is arising and, nivolumab, a programmed cell death 1 (PD-1) blocking antibody, and atezolizumab, a programmed cell death-ligand 1 (PD-L1) blocking antibody, have also demonstrated promising results by increasing mRCC overall survival (OS) $[20,21]$. According to the American Cancer Society, patients with localized disease present a five-year survival rate above $75 \%$, whereas for mRCC patients it decreases to less than $15 \%$. Poor prognosis of advanced RCC can be explained by a wide variety of factors, with the acquired resistance to targeted therapies the main one [22]. Currently, no adequate tools for the screening or early diagnosis of RCT are available. Furthermore, prognostication is mainly based on clinical stage and metastatic dissemination, and therapy efficacy is rather poor. Thus, the development and clinical implementation of more robust, reliable, and cost-effective biomarkers capable of RCTs' early-stage detection and/or prediction of disease progression and therapy response is mandatory. To tackle these limitations, tumor-related genetic and/or epigenetic alterations may be used as biomarkers [23], ultimately improving patient survival and quality of life, while reducing healthcare costs through avoidance of futile therapeutic interventions.

\section{Epigenetics}

Epigenetics, firstly termed by Conrad Waddington in 1942, refers to mitotically and/or meiotically heritable and reversible changes in gene expression, which do not alter primary nucleotide sequence [24]. Epigenetic regulation involves four major types of modifications: DNA methylation, histone modifications/variants, chromatin remodeling complexes, and non-coding RNAs (ncRNAs) [23,24]. The first three control chromatin architecture, regulating gene expression (Figure 1). The transcriptional outcome of DNA methylation is genome location-dependent, since gene promoter DNA methylation leads to transcription repression, while gene body DNA methylation is associated with transcription activation. Histone-tail methylation is residue-specific, often leading to repressive marks and increased chromatin condensation, while acetylation results in activation marks and looser chromatin architecture [23]. Abnormalities in the normal function of the epigenetic machinery have been linked to several human conditions, including cancer [23]. Epigenetic deregulation often occurs early in tumorigenesis leading to a switch in the normal epigenetic patterns and accumulates during disease progression [25]. It is acknowledged that some of these epigenetic alterations might occur prior to the emergence of the malignant phenotype, thus constituting a valuable marker for cancer screening. From a technical point of view, methodologies available to detect those epigenetic marks are sensitive and robust, enabling easy measurement across individuals and with high-throughput screening potential [26]. 


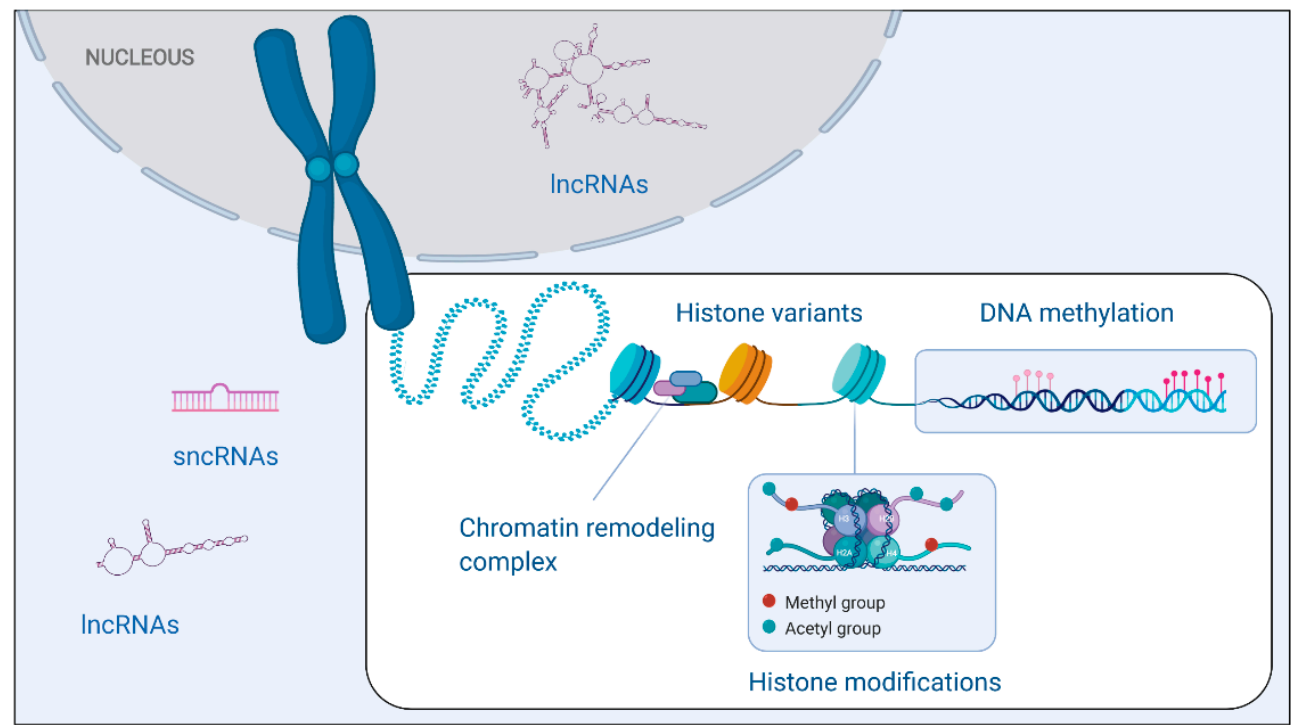

Figure 1. Schematic representation of epigenetic machinery components. DNA methylation is catalyzed by DNA methyl transferases (DNMT) and consists of covalent addition of a methyl group to the 5-carbon of the cytosine ring resulting in 5-methylcytosine $(5-\mathrm{mC})$. Histone post-transcriptional modifications constitute another type of epigenetic-based gene regulatory mechanism. These reactions (e.g., acetylation and methylation) occur in the residues of histone tails and are extremely refined, being catalyzed by highly regulated enzymes. In addition, histones might also have variants, which alter nucleosome functionality. Chromatin remodeling complexes, such as SWItch/Sucrose Non-Fermentable (SWI/SNF), Imitation SWI (ISWI), INO80, and Nucleosome Remodeling Deacetylase (NuRD), alter chromatin architecture, through direct interaction with nucleosomes. Finally, non-coding RNAs, namely small non-coding RNAs (sncRNAs) and long non-coding RNAs (lncRNAs) post-transcriptionally regulate gene expression, both in the nucleus and cytoplasm. Created by BioRender.com (https://biorender.com/)

Global increase in RCT incidence over the last decades and the concerns regarding the most suitable follow-up and treatment for each patient demand reliable biomarkers amenable to clinical use. Herein, we aimed to critically review and highlight the most scientifically relevant and clinically promising studies concerning ncRNA-based biomarkers for RCT detection, prognostication, prediction of response to therapy, and patient monitoring.

\section{Evidence Acquisition}

Bibliography was selected after a PubMed search up to 19 April 2020 using the keywords: Non-coding RNA, biomarkers, and renal cell tumor, which resulted in the analysis of more than 400 manuscripts. All articles' references were also examined for potentially useful studies. Furthermore, relevant articles were selected based on the following criteria: Written in English, the main topic is non-coding RNA, biomarkers, and renal cell carcinoma. Original reports were chosen based on the detail of analysis, mechanistic support of data, novelty, and potential clinical usefulness of the findings. After thorough analysis, 143 original articles were enrolled in the final version of this review.

\section{Non-Coding RNAs (ncRNAs)}

Although most of the genome is transcribed into RNAs, only a small percentage encodes for proteins (1-2\%). Thus, most RNAs are, indeed, ncRNAs, devoid of protein-coding potential [27]. For many years, ncRNAs were thought to be "transcriptional trash". However, this perception has recently changed, and the pivotal roles of ncRNAs in major biological processes, such as imprinting, cell cycle, pluripotency, and gene expression regulation, are now widely acknowledged [28-30]. Based 
on the functional RNA molecule's size, ncRNAs are further categorized into small non-coding RNAs (sncRNAs) if smaller than 200 base pairs in length [31,32] or long non-coding RNAs (lncRNAs) [33,34].

\subsection{Small Non-Coding RNAs (sncRNAs)}

The classification of sncRNAs as epigenetic mechanism of gene expression control remains controversial. Several studies have pointed that sncRNAs' mechanism of action is post-transcriptional and should not be thus classified as epigenetic regulators, whereas others have a contrasting view. Nevertheless, this subclass of ncRNAs is biologically relevant. MicroRNAs (miRNAs) are the most well studied of these small molecules [35]. This class of small ncRNAs are 18-25 nucleotides in length [24] and regulate gene expression through RNA interference (RNAi) [23]. In the human genome, miRNAs are encoded by individual genes or clusters of few to several hundred different miRNAs genes [36]. The latter are then transcribed as polycistronic transcripts, which are ultimately processed into the individual mature miRNAs. In most cases, miRNAs are encoded by introns of non-coding or coding genes, but they can also be encoded by exonic regions [37]. Following transcription by RNA polymerase II, the primary miRNA (pri-miRNA) undergoes several steps of maturation, catalyzed by type III ribonucleases (RNases). First, in the nucleus, the Drosha complex cleaves the pri-miRNA, leading to the formation of the precursor miRNA (pre-miRNA). Then, after pre-miRNA transport to the cytoplasm, Dicer complex cleaves the molecule, generating a miRNA duplex, which is loaded into the pre-miRNA-inducing silencing complex (pre-miRISC), where the stable $5^{\prime}$ end strand-guide strand-is selected, generating the mature miRISC complex, whereas the other strand-passenger strand-is rapidly degraded [38]. Together with GW182 family of proteins, miRISC binds to mRNA targets by base complementarity and, ultimately, leads to gene silencing. Another type of sncRNAs are the P-element Induced Wimpy testis (PIWI)-interacting RNAs (piRNAs). First discovered in the beginning of the 21st century [39], these 21-35 nucleotide-long molecules are involved in viral infection response, transposable elements silencing, and regulation of gene expression by (1) leading PIWI proteins to cleave target RNA, (2) promoting heterochromatin assembly, and (3) inducing DNA methylation $[40,41]$. One of the main features that distinguishes miRNAs from piRNAs is that the latter have single-strain RNA precursors and its processing requires PIWI proteins of the Argonaute/PIWI family, but does not need DICER complex [42]. Small interfering RNAs (SiRNAs) are also classified as sncRNAs [31], but this review solely focused on miRNAs and piRNAs, as these are the most well studied.

\subsubsection{MiRNAs and piRNAs in RCTs}

Deregulated miRNA expression in cancer was first reported in the early 2000s by Calin and colleagues [43]. Since then, various studies have demonstrated differential miRNA expression profiles in benign and malignant neoplasms compared to healthy individuals. Dysregulation of miRNA expression occurs in various steps of tumorigenesis and in several tumor models [23], including RCT $[24,44]$. MiRNAs possess the ability to target several mRNAs, and one mRNA might be targeted by many miRNAs [45]. Depending on the target, miRNAs are classified as tumor suppressor miRNAs (TSmiRs) or as oncogenic miRNAs (oncomiRs). TSmiRs are usually downregulated in cancer and act through transcriptional repression of oncogenes, whereas oncomiRs are normally upregulated, and act by targeting tumor suppressor genes, leading to mRNA decay and/or degradation [46]. Nonetheless, several reports have demonstrated that, depending on the cellular context and the tumor type, the same miRNA may exhibit oncogenic or tumor suppressor activity, such as let- $7 \mathrm{~g}$, which is downregulated in lung cancer and upregulated in colorectal cancer $[47,48]$.

Concerning piRNAs, most are not complementary to putative target mRNAs, indicating that piRNAs may be involved in epigenetic regulation rather than post-transcriptional regulation, controlling a variety of biological processes and being also implicated in cancer development [49]. Several studies aimed to disclose their biological role in different cancer types [50], including RCC [51-53]. However, 
the specific molecular mechanism underlying piRNAs' deregulation in carcinogenesis is still poorly understood, and further investigation is needed.

Due to their tissue and cellular-specific functions and expression, the potential use of sncRNAs as diagnostic, prognostic, predictive, and monitoring cancer biomarkers has been extensively studied in the recent years. Here, we highlighted the most promising findings in RCT, both in tissue and liquid biopsies.

\subsubsection{SncRNAs as Diagnostic Biomarkers}

\section{Tissue-Based Samples}

The increasing number of asymptomatic, incidentally detected renal masses constitutes a major clinical challenge, considering the need to define the potential threat to the life of the patient. Whether a biopsy is mandatory or not remains controversial, considering that histopathological and/or cytopathological assessment may not provide a definitive diagnosis in a sizeable proportion of cases. Thus, the ability of sncRNAs to discriminate between normal and benign/malignant tissue has been investigated. Wotschofsky and co-workers [54] measured the differential expression of several miRNAs in a series of $111 \mathrm{ccRCC}$ and matched normal tissue (MNT) using quantitative real-time PCR (RT-qPCR). The combination of miR-141, miR-155, and miR-184 identified malignancy with 95\% sensitivity, $100 \%$ specificity, corresponding to an area under curve (AUC) of 0.990 [54]. In another study, miR-141 or miR-200b levels discriminated RCC from normal renal tissue (NRT) with $99.2 \%$ sensitivity, $100 \%$ specificity, and an AUC of 0.991 . Furthermore, the same panel distinguished ccRCC, pRCC, or chRCC from benign renal tumors with $85.6 \%$ sensitivity, 100\% specificity, and an AUC of 0.914 [55]. In 2015, Busch and colleagues [51] reported that piR-30924, piR-57125, and piR-38756 were differentially expressed in ccRCC compared to NRT and the combination of these piRNAs identified malignant disease with $91 \%$ sensitivity, $86 \%$ specificity, and an AUC of 0.910 . Notably, the combination of the duo piR-30924 and piR-57125 distinguished metastatic-ccRCC (mccRCC) from non-metastatic ccRCC (non-mccRCC) with 73.0 sensitivity, 74.0 specificity, and an AUC of 0.760 [51]. Several other studies have been published since, and are summarized in Table 1. Because tissue biopsies are seldom performed and might not represent the entire lesion, these biomarkers might assist in the correct classification of the tumor. Moreover, this is an invasive procedure, which submits patients to stress and pain, eventually associated with increased risk of metastization, especially in ccRCC. Hence, discovery and validation of non-invasive screening/diagnosis biomarkers, capable of accurately identifying the nature of renal masses, is urgently needed. 
Table 1. Summary of proposed diagnostic biomarkers for Renal Cell Tumors (RCT) in tissue.

\begin{tabular}{|c|c|c|c|c|c|c|c|}
\hline \multirow{2}{*}{ Year } & \multirow{2}{*}{$\begin{array}{l}\text { Diagnostic } \\
\text { Biomarker }\end{array}$} & \multirow{2}{*}{$\begin{array}{l}\text { Biological } \\
\text { Source }\end{array}$} & \multirow{2}{*}{ Number of Cases/Controls } & \multicolumn{3}{|c|}{ Diagnostic Performance } & \multirow{2}{*}{ Reference } \\
\hline & & & & Sensitivity (\%) & Specificity $(\%)$ & AUC & \\
\hline 2009 & miR-200c & Tissue & 72 ccRCC; 72 MNT & n.a. & n.a. & 0.970 & [56] \\
\hline 2010 & miR-200c & Tissue & 13 chRCC; 21 oncocytomas & n.a. & n.a. & 0.880 & [57] \\
\hline 2012 & $\mathrm{miR}-21$ & Tissue & 71 ccRCC \& 18 pRCC; 10 chRCC \& 8 oncocytomas & 83.0 & 90.0 & 0.886 & [58] \\
\hline 2013 & $3 \mathrm{miR}$ panel & Tissue & 111 ccRCC; 111 MNT & 95.0 & 100.0 & 0.990 & [54] \\
\hline 2013 & miR-210 + let-7c & Tissue & 16 pRCC type I; 17 pRCC type II & n.a. & n.a. & 0.919 & [59] \\
\hline 2013 & miR-200b & Tissue & 90 RCC; 30 oncocytomas & 96.7 & 90.0 & 0.914 & [55] \\
\hline 2014 & miR-3687 & Tissue & 24 ccRCC; 40 NRT & n.a. & n.a. & 0.847 & [60] \\
\hline 2014 & miR-141 & Tissue & 68 ccRCC; 68 MNT & 86.8 & 97.1 & 0.930 & [61] \\
\hline 2014 & miR-129-3p & Tissue & 69 ccRCC; 69 MNT & 75.9 & 62.1 & 0.735 & [62] \\
\hline 2014 & $5 \mathrm{miR}$ panel & Tissue & 32 ccRCC; 16 NRT & 100.0 & 100.0 & 1.000 & [63] \\
\hline 2015 & 3 piRNA panel & Tissue & 106 ccRCC; 77 NRT & 91.0 & 86.0 & 0.910 & [51] \\
\hline 2016 & miR-145 & Tissue & 44 RCC; 44 MNT & n.a. & n.a. & 0.616 & [64] \\
\hline 2016 & miR-141 & Tissue & 27 ccRCC; 27 MNT & n.a. & n.a. & 0.912 & [65] \\
\hline 2016 & piR-823 & Tissue & 153 RCC; 121 MNT & n.a. & n.a. & 0.795 & [53] \\
\hline 2017 & $4 \mathrm{miR}$ panel & Tissue & 48 ccRCC; 50 benign renal tumors & 91.7 & 94.0 & 0.992 & [66] \\
\hline 2017 & $\mathrm{miR}-34 \mathrm{a}$ & Tissue & 85 RCC; 85 MNT & n.a. & n.a. & 0.854 & [67] \\
\hline 2017 & miR-200c & Tissue & 19 chRCC; 11 oncocytomas & 84.0 & 82.0 & 0.820 & [68] \\
\hline 2017 & miR-200c & Tissue & 30 ccRCC; 30 MNT & n.a. & n.a. & 0.860 & [69] \\
\hline 2017 & miR-720 & Tissue & 30 RCC; 30 NRT & 80.0 & 100.0 & 0.905 & [70] \\
\hline 2018 & $\mathrm{miR}-203$ & Tissue & 53 ccRCC; 53 MNT & n.a. & n.a. & 0.944 & [71] \\
\hline 2018 & miR-182-5p & Tissue & 24 ccRCC; 24 MNT & n.a. & n.a. & 0.954 & [72] \\
\hline 2018 & miR-224/miR-141 & Tissue & 68 ccRCC; 68 MNT & 97.1 & 98.5 & 0.990 & [73] \\
\hline 2018 & $\operatorname{miR}-452-5 p$ & Tissue & 20 RCC; 20 MNT & n.a. & n.a. & 0.919 & [74] \\
\hline 2019 & piR-34536 & Tissue & 118 ccRCC; 75 NRT & 78.0 & 78.1 & 0.815 & [75] \\
\hline
\end{tabular}

MNT—-matched normal tissue; NRT—normal renal tissue; RCC—renal cell carcinoma; ccRCC—clear cell renal cell carcinoma; pRCC—papillary renal cell carcinoma; chRCC—chromophobe renal cell carcinoma; n.a.—not available. 
Liquid Biopsies

Recently, detection and characterization of circulating sncRNAs might represent a promising non-invasive technique to identify RCT [76]. SncRNAs are highly stable and abundant in plasma, serum, and other body fluids, being released from damaged or apoptotic normal cells, as well as from tumor cells. Numerous reports have proposed several RCT biomarkers in liquid biopsies. Serum samples were firstly used in a study by Wulfken and colleagues [77], which demonstrated that serum miR-1233 expression levels discriminated cancer patients from asymptomatic controls (AC) with $77.4 \%$ sensitivity and $37.6 \%$ specificity. The limited performance of this marker compared to tissue-based studies might be explained by technical limitations. Since then, methodology has improved, and miR-210 expression levels were found to discriminate ccRCC and AC in serum samples with $81.0 \%$ sensitivity and 79.4\% specificity [78]. Recently, miR-1233 and miR-210 levels, in serum and in exosomes, discriminated ccRCC from healthy controls with 81.0/70.0\% sensitivity and 76.0/62.2\% specificity, respectively, with exosome-derived samples showing a better biomarker performance [79]. Moreover, plasma samples have also been tested. Specifically, miR-21 and miR-106a isolated from plasma ( 30 ccRCC and $30 \mathrm{AC}$ ) disclosed the ability to identify renal malignancy with $77.3 \%$ sensitivity and $96.4 \%$ specificity for the former miR and $86.7 \%$ sensitivity and $70.0 \%$ specificity for the latter [80]. Subsequently, Lou and colleagues [81] showed that miR-144-3p detected RCT with $87.1 \%$ sensitivity and 83.0\% specificity. Notably, miR-144-3p was also able to distinguish ccRCC from benign mesenchymal tumors (angiomyolipomas) with $75.0 \%$ sensitivity and $71.7 \%$ specificity [81]. Finally, diagnostic biomarkers have also been tested in urine samples. In 2016, Butz and colleagues [82] reported that miR-126-3p and miR-34b-5p, isolated from urine exosomes, could discriminate ccRCC from healthy controls with $77.5 \%$ sensitivity and $72.4 \%$ specificity. Remarkably, both miRs also distinguished benign lesions from normal with $75.0 \%$ sensitivity and $82.8 \%$ [82]. Additionally, urinary miR-15a expression levels, evaluated in $67 \mathrm{RCT}$ patients and $15 \mathrm{AC}$, detected malignancy with $98.1 \%$ sensitivity and $100 \%$ specificity [83]. A summary of these and other studies is depicted in Table 2. 
Table 2. Overview of different proposed diagnostic biomarkers for RCT in liquid biopsies.

\begin{tabular}{|c|c|c|c|c|c|c|c|}
\hline \multirow{2}{*}{ Year } & \multirow{2}{*}{ Diagnostic Biomarker } & \multirow{2}{*}{ Biological Source } & \multirow{2}{*}{ Number of Cases/Controls } & \multicolumn{3}{|c|}{ Diagnostic Performance } & \multirow{2}{*}{ Reference } \\
\hline & & & & Sensitivity (\%) & Specificity (\%) & AUC & \\
\hline 2011 & miR-1233 & Serum & 84 RCC; 93 AC & 77.4 & 37.6 & 0.588 & [77] \\
\hline 2012 & miR-378 + miR-451 & Serum & 90 RCC; 35 AC & 81.0 & 83.0 & 0.860 & [84] \\
\hline 2013 & miR-210 & Serum & 68 ccRCC; $42 \mathrm{AC}$ & 81.0 & 79.4 & 0.874 & [78] \\
\hline 2014 & $\mathrm{miR}-210$ & Serum & 34 ccRCC; $23 \mathrm{AC}$ & 65.0 & 83.0 & 0.770 & [85] \\
\hline 2014 & miR-221 & Plasma & $43 \mathrm{RCC} ; 34 \mathrm{AC}$ & 72.5 & 33.3 & 0.696 & [86] \\
\hline 2015 & $5 \mathrm{miR}$ panel & Serum & 76 stage I ccRCC; 107 AC & 80.0 & 71.0 & 0.807 & [87] \\
\hline 2015 & miR-210 + miR-378 & Serum & $195 \mathrm{RCC} ; 100 \mathrm{AC}$ & 80.0 & 78.0 & 0.848 & [88] \\
\hline 2016 & miR-126-3p + miR-486-5p & Urine exosomes & 24 benign renal tumors; $33 \mathrm{AC}$ & 75.0 & 87.5 & 0.850 & [82] \\
\hline \multirow{2}{*}{2016} & \multirow{2}{*}{ piR-823 } & Serum & 178 RCC; $101 \mathrm{AC}$ & n.a. & n.a. & 0.626 & \multirow{2}{*}{ [53] } \\
\hline & & Urine & 20 RCC; 15 AC & n.a. & n.a. & 0.743 & \\
\hline 2017 & miR-144-3p & Plasma & 106 ccRCC; $123 \mathrm{AC}$ & 87.1 & 83.0 & 0.910 & [81] \\
\hline 2017 & miR-21 & Plasma & 30 ccRCC; $30 \mathrm{AC}$ & 77.3 & 96.4 & 0.865 & [80] \\
\hline 2017 & miR-210 & Urine & 75 ccRCC; 45 AC & 57.8 & 80.0 & 0.760 & [89] \\
\hline 2017 & Let-7a & Urine & 69 ccRCC; 36 AC & 71.0 & 81.0 & 0.831 & [90] \\
\hline 2017 & miR-451 & Plasma & 94 ccRCC; $100 \mathrm{AC}$ & n.a. & n.a. & 0.640 & [91] \\
\hline 2018 & miR-1233 & Serum exosomes & 80 ccRCC; 82 AC & 81.0 & 76.0 & 0.820 & [79] \\
\hline 2018 & miR-15a & Urine & $67 \mathrm{RCT} ; 15 \mathrm{AC}$ & 98.1 & 100 & 0.955 & [83] \\
\hline 2018 & miR-210 × miR-224 & Plasma & 66 ccRCC; $67 \mathrm{AC}$ & 92.5 & 45.5 & 0.659 & [73] \\
\hline 2018 & miR-210 & Serum exosomes & 45 ccRCC; $30 \mathrm{AC}$ & 82.5 & 80.0 & 0.878 & [92] \\
\hline 2019 & miR-508-3p \& miR-885-5p & Serum & 85 ccRCC; 35 AC & n.a. & n.a. & 0.900 & [93] \\
\hline 2020 & miR-432-5p & Urine & 44 ccRCC-SRM; 27 oncocytomas & n.a. & n.a. & 0.710 & [94] \\
\hline 2020 & miR-30a-5p ${ }^{m e}$ & Urine & 171 ccRCC; 85 AC & 63.0 & 67.0 & 0.670 & [95] \\
\hline
\end{tabular}

RCC—renal cell carcinoma; ccRCC—clear cell renal cell carcinoma; RCT—renal cell tumor; ccRCC-SRM—clear cell renal cell carcinoma-small renal mass; AC—asymptomatic controls; me-promoter methylation; n.a.-not available. 


\subsubsection{SncRNAs as Prognostic Biomarkers}

\section{Tissue-Based Samples}

Several sncRNAs have also been proposed as predictors of disease progression and outcome. Currently, RCT prognosis is mainly based on clinical stage and other clinical parameters at diagnosis. Nonetheless, specific sncRNAs might complement the currently used clinicopathological parameters, to improve patient management. In 2013, Wang and colleagues [96] reported that RCC patients disclosing higher miR-100 expression levels endured significantly shorter overall survival (OS), multiplying by a factor of three the risk of death comparing to those with low expression. Likewise, increased miR-630 expression levels independently predicted shorter OS, in multivariable analysis [97]. Importantly, sncRNAs have shown promise as predictors of disease-progression. Samaan and colleagues [98] divided their 258 ccRCC patient cohort into either miR-210 positive or negative expression groups. The first group of patients displayed markedly reduced disease-free survival (DFS) (hazard ratio (HR): 1.91; 95\% confidence interval (CI): 1.10-3.310) compared to the negative expression group [98]. The same trend was observed in two subsequent studies, in which higher miR-210 expression associated with worse survival $[99,100]$, whereas in another study increased miR-210 expression levels in ccRCC tissue associated with better survival [101]. Thus, multicentric studies with larger cohorts are needed to unveil the exact prognostic value of miR-210. Furthermore, high miR-27a-3p expression levels associated with shorter progression-free survival (PFS) [102], whereas low miR-155 expression entailed 5-fold increase risk to die from the disease. Notably, both miR-27a-3p and miR-155 expression levels were independent predictors of cancer-specific survival (CSS) in advanced ccRCC (stages III and IV) [103]. Table 3 summarizes these and other relevant findings concerning the prognostic value of miRNAs in RCC. 
Table 3. List of potential prognostic Renal Cell Carcinoma (RCC) biomarkers in tissue samples.

\begin{tabular}{|c|c|c|c|c|c|c|c|c|}
\hline \multirow{2}{*}{ Year } & \multirow{2}{*}{ Prognostic Variable } & \multirow{2}{*}{ Prognostic Biomarker } & \multirow{2}{*}{ Biological Source } & \multirow{2}{*}{ Number of Cases } & \multirow{2}{*}{ Poor Prognosis } & \multicolumn{2}{|c|}{ Prognostic Performance } & \multirow{2}{*}{ Reference } \\
\hline & & & & & & HR & $95 \%$ CI & \\
\hline 2010 & RFS & miR-9-3 & Tissue & 59 ccRCC & High methylation & 5.850 & $1.300-26.35$ & [104] \\
\hline 2012 & CSS & $4 \mathrm{miR}$ panel & Tissue & $68 \mathrm{ccRCC}$ & High risk & $8.800 *$ & $2.620-29.58^{*}$ & [105] \\
\hline 2012 & DFS & miR-21 & Tissue & 87 RCC & Positive expression & $2.150 *$ & $1.160-3.980 *$ & {$[58]$} \\
\hline 2013 & RFS & miR-124-3 & Tissue & 80 ccRCC & High methylation & 9.370 & $2.680-32.80$ & [106] \\
\hline 2013 & RFS & miR-514 & Tissue & 87 ccRCC & Low expression & 0.250 & $0.080-0.750$ & [54] \\
\hline 2013 & OS & miR-210 & Tissue & 46 ccRCC & Low expression & 3.010 & $1.390-6.510$ & [101] \\
\hline 2013 & CSS & $\mathrm{miR}-486$ & Tissue & $46 \mathrm{RCC}$ & High expression & 4.330 & $1.450-18.71$ & [107] \\
\hline 2013 & OS & miR-100 & Tissue & 96 RCC & High expression & 3.600 & $1.800-5.200$ & [96] \\
\hline 2013 & CSS & miR-155 & Tissue & $137 \mathrm{ccRCC}$ & Low expression & 5.490 & $2.400-12.52$ & [103] \\
\hline 2014 & DFS & $\mathrm{miR}-21 \& \mathrm{miR}-126$ & Tissue & $103 \mathrm{ccRCC}$ & High risk & 19.37 & $4.060-92.44$ & [108] \\
\hline 2014 & OS & miR-630 & Tissue & 92 ccRCC & High expression & 3.021 & $2.074-5.726$ & [97] \\
\hline 2014 & DSS & $\mathrm{miR}-21 / \mathrm{miR}-10 \mathrm{~b}$ & Tissue & $105 \mathrm{ccRCC}$ & High ratio & 2.624 & $1.201-5.736$ & [109] \\
\hline 2014 & DFS & $\mathrm{miR}-129-3 p$ & Tissue & 48 ccRCC & Low expression & 3.119 & $1.060-9.175$ & [62] \\
\hline 2014 & RFS & miR-125b & Tissue & 200 ccRCC & High expression & 3.931 & $1.213-12.74$ & [110] \\
\hline 2015 & OS & $\mathrm{miR}-497$ & Tissue & 86 ccRCC & Low expression & 2.583 & $1.691-6.361$ & [111] \\
\hline 2015 & DFS & miR-210 & Tissue & 258 ccRCC & Positive expression & 1.910 & $1.010-3.310$ & [98] \\
\hline 2015 & DFS & miR-126 & Tissue & 260 ccRCC & Negative expression & $0.300 *$ & $0.180-0.500$ * & [112] \\
\hline 2015 & OS & $\mathrm{miR}-506$ & Tissue & $106 \mathrm{ccRCC}$ & Low expression & 3.886 & $2.179-7.524$ & [113] \\
\hline 2015 & OS & miR-203 & Tissue & $90 \mathrm{ccRCC}$ & Low expression & 3.071 & $1.719-6.374$ & [114] \\
\hline 2015 & CSS & $\operatorname{miR}-21$ & Tissue & 45 RCC & High expression & 6.460 & $1.350-30.94$ & [115] \\
\hline 2015 & CSS & piR-43607 & Tissue & $68 \mathrm{ccRCC}$ & High expression & $1.240 *$ & $1.082-1.445$ * & [52] \\
\hline 2015 & OS & miR-124-3p & Tissue & $62 \mathrm{ccRCC}$ & Low expression & $2.600 *$ & $1.069-7.262 *$ & [116] \\
\hline 2015 & RFS & piR-38756 & Tissue & 72 ccRCC & High expression & 3.150 & $1.960-9.320$ & [51] \\
\hline 2015 & PFS & $\mathrm{miR}-27 \mathrm{a}-3 \mathrm{p}$ & Tissue & 140 ccRCC & High expression & 2.710 & $1.230-6.420$ & [102] \\
\hline 2016 & DFS & miR-194 & Tissue & $234 \mathrm{ccRCC}$ & Negative expression & 0.520 & $0.270-0.980$ & [117] \\
\hline 2016 & DFS & miR-19a & Tissue & 197 ccRCC & High expression & 2.410 & $1.217-4.773$ & [118] \\
\hline 2016 & PFS & $\mathrm{miR}-222-3 p$ & Tissue & $74 \mathrm{ccRCC}$ & High expression & 2.020 & $1.510-2.710$ & [119] \\
\hline
\end{tabular}


Table 3. Cont

\begin{tabular}{|c|c|c|c|c|c|c|c|c|}
\hline \multirow{2}{*}{ Year } & \multirow{2}{*}{ Prognostic Variable } & \multirow{2}{*}{ Prognostic Biomarker } & \multirow{2}{*}{ Biological Source } & \multirow{2}{*}{ Number of Cases } & \multirow{2}{*}{ Poor Prognosis } & \multicolumn{2}{|c|}{ Prognostic Performance } & \multirow{2}{*}{ Reference } \\
\hline & & & & & & HR & $95 \% \mathrm{CI}$ & \\
\hline 2017 & CSS & miR-223-3p & Tissue & 78 ccRCC & High expression & 3.510 & $1.600-7.690$ & [66] \\
\hline 2017 & DFS & $\mathrm{miR}-10 \mathrm{~b}$ & Tissue & 246 ccRCC & Negative expression & $0.470 *$ & $0.280-0.790$ * & [120] \\
\hline 2017 & OS & miR-766-3p & Tissue & $75 \mathrm{RCC}$ & Low expression & 2.700 & $1.310-5.530$ & [121] \\
\hline 2018 & OS & $\mathrm{miR}-566$ & Tissue & $42 \mathrm{ccRCC}$ & High expression & 0.060 & $0.005-0.769$ & [122] \\
\hline 2018 & OS & $\mathrm{miR}-18-5 \mathrm{p}$ & Tissue & $42 \mathrm{RCC}$ & High expression & 0.175 & $0.032-0.953$ & [123] \\
\hline 2018 & OS & $\operatorname{miR}-663 a$ & Tissue & $42 \mathrm{ccRCC}$ & High expression & 5.132 & $1.039-25.350$ & {$[124]$} \\
\hline 2018 & OS & $\mathrm{miR}-572$ & Tissue & $42 \mathrm{RCC}$ & High expression & 0.174 & $0.034-0.878$ & [125] \\
\hline 2018 & RFS & miR-155-5p \& miR-210-3p & Tissue & 205 ccRCC & High risk & 2.700 & $1.280-5.680$ & [100] \\
\hline 2018 & OS & miR-452-5p & Tissue & 102 RCC & High expression & 1.580 & $1.070-2.310$ & [74] \\
\hline 2019 & OS & $\mathrm{miR}-23 a-5 p$ & Tissue & 118 RCC & High expression & 3.270 & $1.552-6.893$ & [126] \\
\hline 2019 & OS & miR-183-5p & Tissue & 284 ccRCC & High expression & 0.550 & $0.364-0.832$ & [127] \\
\hline 2019 & OS & miR-3133 & Tissue & 135 ccRCC & Low expression & 2.802 & $1.391-5.646$ & [128] \\
\hline 2019 & OS & $\mathrm{miR}-221-5 \mathrm{p}$ & Tissue & $196 \mathrm{ccRCC}$ & High expression & 0.550 & $0.326-0.926$ & [129] \\
\hline 2019 & PFS & piR-51810 & Tissue & 118 ccRCC & Low expression & 0.431 & $0.190-0.975$ & [75] \\
\hline 2019 & OS & miR-142-3p & Tissue & 284 RCC & High expression & 0.525 & $0.347-0.796$ & [130] \\
\hline 2019 & OS & $\mathrm{miR}-106 \mathrm{~b}-5 \mathrm{p}$ & Tissue & 284 ccRCC & High expression & 0.496 & $0.327-0.752$ & [131] \\
\hline 2019 & MFS & $4 \mathrm{miR}$ panel & Tissue & 85 ccRCC & High risk & 12.402 & $3.586-42.893$ & [132] \\
\hline 2020 & DFS & miR-30a-5pme & Tissue & $227 \mathrm{ccRCC}$ & High methylation & 5.174 & $1.228-21.808$ & [95] \\
\hline
\end{tabular}

*-univariable analysis; HR—hazard ratio; 95\% CI—95\% confidence interval; OS—overall survival; DFS—disease-free survival; PFS—progression-free survival; MFS—-metastasis-free survival; CSS—cancer-specific survival; RFS—recurrence-free survival. 
Liquid Biopsies

Studies on sncRNAs as potential biomarkers for RCC progression and/or disease outcome in liquid biopsies are rather scarce. Let-7i-5p low expression in exosomes from plasma of $65 \mathrm{mRCC}$ patients associated with shorter OS [133]. Fujii and colleagues [134] showed that higher plasma-derived exosomal miR-224 expression levels negatively associated with shorter OS, CSS, and recurrence-free survival (RFS). A subsequent analysis of 67 ccRCC serum samples demonstrated that increased miR-206 and miR-122-5p expression associated with increased risk of disease progression and mortality, although, in multivariable analysis, only miR-206 retained independent value as predictor of PFS [135]. Finally, Dias and colleagues reported that higher miR-210, miR-221, and miR-1233 plasma levels associated with shorter CSS [99]. Detailed information of all relevant studies may be found in Table 4.

\subsubsection{SncRNAs as Predictive Biomarkers of Response to Therapy}

\section{Tissue-Based Samples}

Uncertainties concerning efficacy and deleterious side effects of RCC therapy negatively impact patient management [136-138]. Ideally, each patient should be prescribed the therapy most likely to specifically target and eliminate neoplastic cells, which sets the basis for precision medicine [139]. Considering their involvement in critical metabolic pathways, it is unsurprising that sncRNAs have been implicated in cancer therapy resistance [140-142]. Furthermore, sncRNAs have been proposed as predictors of response to therapy in RCC. Indeed, miR-141 expression levels were shown to predict response to sunitinib, as patients with low levels disclosed a significantly worse response [143]. In a different study, lower expression levels of both miR-155 (a well-known oncomiR) and miR-484 (with biological role yet to be fully understood) associated with increased time to progression (TTP) in a series of 63 mRCC patients (44 responders and 19 non-responders) treated with sunitinib [144]. Recently, Go and colleagues demonstrated that miR-421 was highly expressed in RCC tissues from patients who did not respond to VEGFR-TKI [145]. Table 5 provides additional information on the most relevant studies concerning the predictive value of sncRNAs in RCC. 
Table 4. Prognostic small non-coding RNAs (sncRNAs) for RCC in liquid biopsies.

\begin{tabular}{|c|c|c|c|c|c|c|c|c|}
\hline \multirow{2}{*}{ Year } & \multirow{2}{*}{$\begin{array}{c}\text { Prognostic } \\
\text { Variable }\end{array}$} & \multirow{2}{*}{ Prognostic Biomarker } & \multirow{2}{*}{ Biological Source } & \multirow{2}{*}{ Number of Cases } & \multirow{2}{*}{ Poor Prognosis } & \multicolumn{2}{|c|}{ Prognostic Performance } & \multirow{2}{*}{ Reference } \\
\hline & & & & & & HR & $95 \% \mathrm{CI}$ & \\
\hline 2014 & CSS & $\mathrm{miR}-221$ & Plasma & $43 \mathrm{RCC}$ & High expression & 10.70 & $1.330-85.65$ & {$[86]$} \\
\hline 2017 & OS & let-7i-5p & Plasma exosomal & 65 RCC & Low expression & 0.566 & $0.374-0.857$ & [133] \\
\hline 2017 & CSS & miR-210 \& miR-221 \& miR-1233 & Plasma & 50 ccRCC & High risk & 3.890 & $1.260-12.01$ & [99] \\
\hline 2017 & PFS & miR-224 & Plasma exosomal & 108 ccRCC & High expression & 11.00 & $3.300-68.70$ & [134] \\
\hline 2017 & DSS & $\mathrm{miR}-150$ & Plasma & $94 \mathrm{ccRCC}$ & Low expression & 1.280 & $1.020-1.670$ & [91] \\
\hline 2018 & PFS & $\mathrm{miR}-206$ & Serum & $67 \mathrm{ccRCC}$ & High expression & 3.670 & $1.290-10.51$ & [135] \\
\hline 2020 & OS & miR-328-3p & Urine & $44 \mathrm{ccRCC}$ & Low expression & 0.290 & $0.080-1.030$ & [94] \\
\hline 2020 & DSS & $m i R-30 a-5 p^{m e}$ & Urine & $53 \mathrm{ccRCC}$ & High methylation & 9.376 & $1.158-75.903$ & [95] \\
\hline
\end{tabular}

HR—hazard ratio; 95\% CI—95\% confidence interval; OS—overall survival; DSS—disease-specific survival; PFS—progression-free survival; CSS—cancer-specific survival.

Table 5. Therapy predictive sncRNAs for RCC in tissue, liquid biopsies, and in vitro studies.

\begin{tabular}{|c|c|c|c|c|c|c|}
\hline Year & Predictive Biomarker & Biological Source & Number of Cases/Cell Lines & Type of Therapy & Main Findings & Reference \\
\hline 2012 & multi-miR panels & Whole blood & $38 \mathrm{ccRCC}$ & Targeted therapy & $\begin{array}{l}\text { Several miRs } \Rightarrow \text { prolonged } \\
\text { or poor response to sunitinib }\end{array}$ & [146] \\
\hline 2013 & miR-141 & Tissue/in vitro & $20 \mathrm{ccRCC}$ & Targeted Therapy & $\downarrow \mathrm{miR}-141 \Rightarrow$ poor response to sunitinib & [143] \\
\hline 2013 & miR-381 & In vitro & $786-\mathrm{O}$ & Chemotherapy & $\begin{array}{c}\mathrm{MiR}-381+5-\mathrm{FU} \Rightarrow \text { lower } \\
\text { proliferation, and } \uparrow 5 \text {-FU efficacy }\end{array}$ & [147] \\
\hline 2014 & miR-942 & Tissue/in vitro & 20 RCC \& Caki-2 & Targeted Therapy & MiR-942 $\Rightarrow$ sunitinib resistance $\Rightarrow \downarrow$ TTP \& OS & [148] \\
\hline 2014 & miR-200c & In vitro & $\begin{array}{c}\text { HEK293, SN12C, } \\
\text { ACHN, 786-O \& Caki-1 }\end{array}$ & Targeted Therapy & $\begin{array}{l}\text { Mimic miR-200c } \Rightarrow \text { sensitivity } \\
\text { to therapy with TKI }\end{array}$ & [149] \\
\hline 2015 & $\operatorname{miR}-27 b$ & In vitro/in vivo & ACHN, 769-P, 786-O \& Caki-1 & Chemotherapy & $\begin{array}{c}\text { Overexpressing } \mathrm{miR}-27 \mathrm{~b} \Rightarrow \\
\text { sensitizes RCC cells to a variety of } \\
\text { anti-cancer drugs, such as doxorubicin }\end{array}$ & [150] \\
\hline 2015 & $\mathrm{miR}-30 \mathrm{a}$ & Tissue/in vivo & 10 ccRCC \& A498 + 786-O & Targeted Therapy & $\begin{array}{l}\text { Exogenously expression of miR-30a } \\
\Rightarrow \uparrow \text { sorafenib treatment efficacy }\end{array}$ & [151] \\
\hline 2015 & $\mathrm{miR}-200 \mathrm{c}$ & In vitro & $\begin{array}{c}\text { Caki-1, Caki-2, A498, ACHN, } \\
\text { 786-O \& 769-P }\end{array}$ & Chemotherapy & $\downarrow \mathrm{miR}-200 \mathrm{c} \Rightarrow$ resistance to docetaxel & [152] \\
\hline
\end{tabular}


Table 5. Cont.

\begin{tabular}{|c|c|c|c|c|c|c|}
\hline Year & Predictive Biomarker & Biological Source & Number of Cases/Cell Lines & Type of Therapy & Main Findings & Reference \\
\hline 2015 & miR-155 \& miR-484 & Tissue & $63 \mathrm{RCC}$ & Targeted Therapy & $\begin{array}{l}\downarrow \text { of both miRs } \Rightarrow \text { better } \\
\text { response to sunitinib } \Rightarrow \uparrow \text { TTP }\end{array}$ & [144] \\
\hline 2015 & $\mathrm{miR}-124$ & In vitro & Caki-2 & Chemotherapy & $\begin{array}{l}\qquad \downarrow \mathrm{miR}-124 \Rightarrow \text { resistance } \\
\text { to doxorubicin and vinblastine }\end{array}$ & [153] \\
\hline 2015 & $\mathrm{miR}-221$ \& miR-222 & Tissue/in vivo & 30 ccRCC \& 786-O + ACHN & Targeted Therapy & $\begin{array}{l}\uparrow \text { of both miRs } \Rightarrow \text { poor } \\
\text { response to sunitinib therapy }\end{array}$ & [154] \\
\hline 2016 & miR-99b-5p & Tissue & $40 \mathrm{ccRCC}$ & Targeted Therapy & $\begin{array}{l}\downarrow \mathrm{miR}-99 \mathrm{~b}-5 \mathrm{p} \Rightarrow \downarrow \text { PFS } \\
\text { and in TKI non-responders }\end{array}$ & [155] \\
\hline 2017 & $\mathrm{miR}-605$ & Serum & 36 ccRCC & Targeted Therapy & $\begin{array}{l}\text { MiR-605 } \Rightarrow \downarrow \text { after vorinostato and } \\
\text { bevacizumab therapy in responders }\end{array}$ & [156] \\
\hline 2017 & $\begin{array}{l}\text { miR-27b \& miR-23b \& } \\
\text { miR-628-5p }\end{array}$ & Tissue & 123 RCC & Targeted Therapy & $\begin{array}{c}\uparrow \text { of these miRs } \Rightarrow \\
\text { long-term sunitinib response }\end{array}$ & [157] \\
\hline 2017 & miR-144-3p & In vitro/in vivo & $\begin{array}{l}\text { 786-O \& SN12-PM6 } \\
\text { + Nude mice }\end{array}$ & Targeted Therapy & $\begin{array}{l}\uparrow \mathrm{miR}-144-3 \mathrm{p} \Rightarrow \downarrow \text { ARID1A } \\
\text { and resistance to sunitinib }\end{array}$ & [158] \\
\hline 2017 & $\operatorname{miR}-451$ & In vitro & ACHN \& GRC -1 & Chemotherapy & $\begin{array}{c}\text { MiR-451 knockdown } \Rightarrow \uparrow \\
\text { sensitivity to adriamycin therapy }\end{array}$ & [159] \\
\hline 2018 & miR-942 \& miR-133 & Tissue & $56 \mathrm{RCC}$ & Targeted Therapy & $\begin{array}{l}\text { Both } \mathrm{miRs} \Rightarrow \text { discriminate between } \\
\text { sunitinib responders and non-responders }\end{array}$ & [160] \\
\hline 2019 & $\operatorname{miR}-421$ & Tissue & $101 \mathrm{MRCC}$ & Targeted Therapy & $\uparrow \mathrm{miR}-421$ in TKI non-responders & [145] \\
\hline 2019 & miR-376b-3p & Tissue & 132 ccRCC & Targeted Therapy & $\downarrow \mathrm{miR}-376 \mathrm{~b}-3 \mathrm{p}$ in sunitinib poor responders & [161] \\
\hline 2020 & $\operatorname{miR}-31-5 p$ & $\begin{array}{l}\text { Exosomes from } \\
\text { plasma/in vitro/in vivo }\end{array}$ & $\begin{array}{l}40 \mathrm{PD} \mathrm{MRCC}+786-\mathrm{O}+ \\
\text { BALB/c nude mice }\end{array}$ & Targeted Therapy & $\begin{array}{l}\uparrow \mathrm{miR}-31-5 \mathrm{p} \text { in PD vs non-PD patients' } \\
\text { plasma samples treated with sorafenib }\end{array}$ & [162] \\
\hline
\end{tabular}

RCC—renal cell carcinoma; ccRCC—clear cell renal cell carcinoma; 5-FU—5-fluorouracil; TTP—time to progression; OS—overall survival; PFS—-progression-free survival; TKI—tyrosine

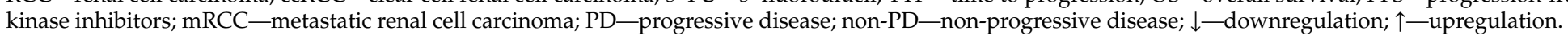


Liquid Biopsies

One of the main drawbacks of tissue-based studies is the inability to capture the dynamic nature of sncRNAs' expression along time, either during disease progression or due to therapeutic intervention. The usage of liquid biopsies might circumvent this limitation, since it allows sample collection at several time points, i.e., prior to, during, and after treatment, enabling patient monitoring. In 2012, Gámez-Pozo and colleagues analyzed the expression of 287 miRs in 38 whole blood samples from patients with advanced RCC treated with sunitinib and constructed multiple models of poor and prolonged response to this TKI. Notably, miR-410, miR-1181, and miR-424 downregulation was associated with prolonged response, whereas low miR-192, miR-193a-3p, and miR-501-3p levels associated with limited response [146]. Additionally, serum miR-605 levels in mccRCC patients treated with vorinostat and bevacizumab were exclusively reduced in the responders' group, comparing to the disease progression group [156]. Additional studies are summarized in Table 5.

\section{In Vitro Studies}

Several studies have been performed in RCC in vitro models in the pursuit of both predictive biomarkers and insights on therapy-resistance mechanisms. Although in vitro models do not fully mimic biological conditions, they allow for the discovery of potential sncRNA-based biomarkers, which may be subsequently validated in clinical samples. Gao and colleagues [149] reported that transfecting mimic miR-200c into ccRCC cell lines resistant to imatinib and sorafenib re-sensitized cells to therapy. Moreover, miR-200c was downregulated in RCC cell lines, whereas one of its targets, CYP1B1, was overexpressed. Remarkably, increased CYP1B1 levels were associated with docetaxel resistance [152]. Additionally, miR-101 downregulation in ccRCC cell lines associated with high UHRF1 (a miR-101 target) levels and, ultimately, to sunitinib resistance [163]. Detailed information on these and other studies can be found in Table 5 .

\subsection{LncRNAs}

As previously mentioned, IncRNAs are a class of ncRNAs with more than 200 base pairs in length $[33,34]$. These molecules can be further categorized into different groups, depending on their genome location, sequence, morphology, structure, and functional features [164,165]. Most lncRNAs are synthesized by the same biogenesis machinery as mRNAs and endure post-transcriptional modifications, such as $5^{\prime}$ terminal methylguanosine cap ( $5^{\prime}$ cap), are often spliced in a canonical manner, and some are $3^{\prime}$ polyadenylated [165]. LncRNAs have a fine-tuned regulation by transcription factors and typically display a tissue-specific expression profile [164]. Functionally, lncRNAs have been implicated in a multitude of biological processes, such as nuclear organization through nucleosome remodeling [166], gene-to-gene interactions [167], and as regulators of miRNA expression [168], thus prompting the hypothesis that lncRNAs' differential expression might be associated with human disease. Indeed, several pathological conditions display aberrant lncRNAs' expression profile [169], including cancer [170].

\subsubsection{LncRNAs in RCT}

LncRNAs have been the focus of several research studies aiming at the discovery of novel biomarkers and understanding the biological mechanisms through which they influence the genesis and progression of RCT [171-173]. Compared to their protein-coding counterparts, lncRNAs are considerably less expressed, which might constitute a major pitfall for their use in clinical practice, since robust detection is quite challenging [174]. Nonetheless, the study of these molecules should be promoted, as technological advances might overcome the present limitations. Herein, we highlighted the most relevant studies reporting lncRNAs as potential diagnostic, prognostic, predictive, and monitoring biomarkers in RCT, both in tissue and liquid biopsies. 


\subsubsection{LncRNAs as Diagnostic Biomarkers}

Tissue-Based Samples

Contrarily to sncRNAs, published data concerning lncRNAs as RCT diagnostic biomarkers are limited. Over two decades ago, Thrash-Bingham and colleagues [175] reported, for the first time, that lncRNA expression was dissimilar among RCC subtypes. Using semiquantitative PCR, a marked increased expression of lncRNA antisense Hypoxia Inducible Factor (aHIF) in ccRCC, comparatively to pRCC, was disclosed [175]. Technology has evolved and these results were subsequently validated in 2011, when Bertozzi and colleagues [176] detected a differential expression of lncRNA aHIF between RCC and MNT, as well as between non-pRCC and pRCC tissue samples. In another study, comprising 102 ccRCC and 50 NRT, lncRNA CYP4A22-2/3 discriminated ccRCC from NRT with an AUC of 0.790 [177]. In 2016, the expression of lncRNA UC009YBY.1 and lncRNA ENST00000514034 was assessed in a set of 70 ccRCC and 70 MNT by Ren and colleagues [178]. These authors reported that the two lncRNAs could identify RCC tissue with $54.29 \%$ sensitivity and $82.86 \%$ specificity for the former, and $60.00 \%$ sensitivity and $67.14 \%$ specificity for the latter [178]. Finally, a recent study reported that lncRNA HOX Transcript Antisense RNA (HOTAIR) might also constitute a ccRCC diagnostic biomarker, disclosing an AUC of 0.9230 [71]. Table 6 summarizes the complete information on relevant published studies reporting lncRNAs as potential RCC diagnostic biomarkers.

Table 6. Long non-coding RNAs (LncRNAs) as potential diagnostic biomarkers in RCC tissues and liquid biopsies.

\begin{tabular}{|c|c|c|c|c|c|c|c|}
\hline Year & $\begin{array}{l}\text { Diagnostic } \\
\text { Biomarker }\end{array}$ & $\begin{array}{l}\text { Biological } \\
\text { Source }\end{array}$ & $\begin{array}{c}\text { Number of } \\
\text { Cases/Controls }\end{array}$ & \multicolumn{3}{|c|}{ Diagnostic Performance } & Reference \\
\hline 1999 & $\mathrm{aHIF}$ & Tissue & 10 ccRCC; 7 pRCC & n.a. & n.a. & n.a. & {$[175]$} \\
\hline 2011 & $\mathrm{aHIF}$ & Tissue & $26 \mathrm{RCC} ; 26 \mathrm{MNT}$ & n.a. & n.a. & n.a. & [176] \\
\hline 2014 & AK096725 & Tissue & $70 \mathrm{RCC} ; 70 \mathrm{MNT}$ & n.a. & n.a. & n.a. & [179] \\
\hline 2015 & CYP4A22-2/3 & Tissue & 102 ccRCC; 50 NRT & n.a. & n.a. & 0.790 & [177] \\
\hline 2016 & TRIM52-AS1 & Tissue & $60 \mathrm{RCC} ; 60 \mathrm{MNT}$ & n.a. & n.a. & n.a. & [181] \\
\hline 2016 & UCA1 & Tissue & 46 RCC; 46 MNT & n.a. & n.a. & n.a. & [182] \\
\hline 2016 & UC009YBY.1 & Tissue & $70 \mathrm{RCC} ; 70 \mathrm{MNT}$ & 54.3 & 82.9 & 0.700 & [178] \\
\hline
\end{tabular}

Liquid Biopsies

Based on our literature search, only two relevant studies evaluating the potential of lncRNAs as RCC diagnostic biomarkers in liquid biopsies were found. Wu and colleagues [183] assessed the expression of five lncRNAs (lncRNA-low expression in tumor (LET), Plasmacytoma Variant Translocation 1 (PVT1), Promoter Of CDKN1A Antisense DNA Damage Activated RNA (PANDAR), Phosphatase and Tensin Homolog Pseudogene 1 (PTENP1), and long intergenic non-protein coding RNA 963 (linc00963)) in two sets of ccRCC and AC serum samples. When combined in a panel, these biomarkers identified malignancy with $79.2 \%$ sensitivity and $88.9 \%$ specificity in the training set (24 ccRCC and $27 \mathrm{AC}$ ) and with $67.6 \%$ sensitivity and $91.4 \%$ specificity in the testing set (37 ccRCC and 35 AC) [183]. Subsequently, serum expression of lncRNA GIHCG was assessed in a set of $46 \mathrm{ccRCC}$ and 46 AC samples. GIHCG expression discriminated ccRCC from healthy donors with $87.0 \%$ sensitivity and $84.8 \%$ specificity. Remarkably, it could also distinguish early-stage ccRCC from AC (31 stage 
I ccRCC vs. 46 ACs) with $80.7 \%$ sensitivity and $84.8 \%$ specificity [184]. The complete information concerning these studies is provided in Table 6, together with tissue-based studies.

\subsubsection{LncRNAs as Prognostic Biomarkers}

Tissue-Based Samples

As for sncRNAs, several reports on the potential of lncRNAs as RCC prognostic biomarkers in tissue samples have been published. In a series of $102 \mathrm{ccRCC}$, Ellinger and colleagues [177] showed that patients disclosing low lncRNA Zinc-Finger protein 180-2 (ZNF180-2) expression endured significantly shorter OS. Notably, lower expression of this lncRNA also correlated with shorter CSS and PFS [177]. In another study, expression levels of lncRNA regulator of Akt Signaling Associated With HCC And RCC (lncARSR) were assessed in a set of 205 ccRCC tissues from patients subdivided into high- and low-expression groups. Patients with lncARSR-high expression displayed significantly shorter RFS, doubling the risk of recurrence comparatively to the lncARSR-low expression group [185]. Furthermore, Bao and colleagues [186] reported that IncRNA PVT1 could serve as independent prognostic biomarker in ccRCC. Indeed, patients with high lncRNA PVT1 expression depicted 1.5 and 3.5 times higher risk of death or recurrence, respectively, compared to patients with low lncRNA PVT1 expression [186]. Recently, in a series of tissues from 204 ccRCC patients, Wang and colleagues [187] found that high lncRNA EGFR-antisense RNA 1 (EGFR-AS1) expression levels increased two-fold the risk of death. Table 7 depicts the complete information on these and other relevant studies assessing the potential of lncRNAs for RCC prognostication. 
Table 7. LncRNAs as potential prognostic biomarkers in RCC tissues.

\begin{tabular}{|c|c|c|c|c|c|c|c|c|}
\hline \multirow{2}{*}{ Year } & \multirow{2}{*}{$\begin{array}{l}\text { Prognostic } \\
\text { Variable }\end{array}$} & \multirow{2}{*}{$\begin{array}{l}\text { Prognostic } \\
\text { Biomarker }\end{array}$} & \multirow{2}{*}{$\begin{array}{c}\text { Biological } \\
\text { Source }\end{array}$} & \multirow{2}{*}{$\begin{array}{l}\text { Number of } \\
\text { Cases }\end{array}$} & \multirow{2}{*}{ Poor Prognosis } & \multicolumn{2}{|c|}{ Prognostic Performance } & \multirow{2}{*}{ Reference } \\
\hline & & & & & & HR & $95 \%$ CI & \\
\hline 2014 & OS & CADM1-AS1 & Tissue & $64 \mathrm{ccRCC}$ & Low expression & 0.211 & $0.088-0.504$ & [188] \\
\hline 2014 & OS & SPRY4-IT1 & Tissue & 98 ccRCC & High expression & 3.375 & $1.824-7.391$ & [189] \\
\hline 2015 & OS & NBAT-1 & Tissue & 98 ccRCC & Low expression & 3.701 & $1.261-9.784$ & [190] \\
\hline 2015 & OS & MALAT1 & Tissue & 106 ccRCC & High expression & 3.086 & $1.813-7.025$ & [191] \\
\hline 2015 & OS & H19 & Tissue & 92 ccRCC & High expression & 3.894 & $1.872-8.014$ & [192] \\
\hline 2015 & PFS & ZNF180-2 & Tissue & 102 ccRCC & Low expression & 0.803 & $0.699-0.922$ & [177] \\
\hline 2016 & OS & Linc00152 & Tissue & 77 ccRCC & High expression & 2.577 & $1.233-5.387$ & [193] \\
\hline 2016 & RFS & lncARSR & Tissue & 205 ccRCC & High expression & 2.023 & $1.213-3.375$ & [185] \\
\hline 2017 & OS & TUG1 & Tissue & 203 ccRCC & High expression & 2.337 & $1.451-6.673$ & [194] \\
\hline 2017 & OS & TCL6 & Tissue & $71 \mathrm{ccRCC}$ & Low expression & 0.130 & $0.020-0.680$ & [195] \\
\hline 2017 & OS & SLINKY & Tissue & $100 \mathrm{ccRCC}$ & High expression & 8.440 & $1.770-40.23$ & [196] \\
\hline 2017 & OS & PANDAR & Tissue & 62 ccRCC & High expression & 1.130 & $0.980-5.120$ & [197] \\
\hline 2017 & OS & MRCCAT1 & Tissue & $68 \mathrm{ccRCC}$ & High expression & 2.306 & $1.003-2.849$ & [198] \\
\hline 2017 & OS & PVT1 & Tissue & 50 ccRCC & High expression & 1.494 & $1.081-2.063$ & [199] \\
\hline 2017 & DFS & MFI2-AS1 & Tissue & 167 ccRCC & Positive expression & 4.240 & $2.070-8.700$ & [200] \\
\hline 2017 & DFS & PVT1 & Tissue & 129 ccRCC & High expression & 3.553 & $1.515-8.329$ & [186] \\
\hline 2018 & OS & ENSG00000241684 & Tissue & $61 \mathrm{ccRCC}$ & Low expression & 5.378 & $2.084-13.88$ & [201] \\
\hline 2018 & OS & LUCAT1 & Tissue & $64 \mathrm{ccRCC}$ & High expression & 3.650 & $1.356-9.826$ & [202] \\
\hline 2018 & OS & CRNDE & Tissue & 112 ccRCC & High expression & 2.023 & $1.039-3.468$ & [203] \\
\hline 2019 & OS & EGFR-AS1 & Tissue & 204 RCC & High expression & 2.204 & $1.145-4.241$ & [187] \\
\hline 2016 & PFS & lncARSR & Plasma & $71 \mathrm{ccRCC}$ & High expression & n.a. & n.a. & [204] \\
\hline 2018 & OS & GIHCG & Serum & 46 ccRCC & High expression & n.a. & n.a. & [184] \\
\hline
\end{tabular}

HR—hazard ratio; 95\% CI—95\% confidence interval; OS—overall survival; DFS—disease-free survival; PFS—progression-free survival; RFS—recurrence-free survival; RCC—renal cell carcinoma; ccRCC—clear cell renal cell carcinoma; n.a.-not available. 
Liquid Biopsies

After literature revision, only two studies reporting on the potential of lncRNAs for RCC's prognostication in liquid biopsies were found. Qu and colleagues [204] assessed the expression of lncARSR in $71 \mathrm{ccRCC}$ plasma samples and verified that higher expression levels were associated with worse PFS. In the other study, serum samples from $46 \mathrm{ccRCC}$ patients were analyzed and increased GIHCG expression levels associated with lower OS [184]. However, both studies lack biomarker prognostic performance analysis, preventing a more robust evaluation of the potential of lncRNAs assessed in liquid biopsies. Table 7 provides the complete information on these two studies.

\subsubsection{LncRNAs as Predictive Biomarkers of Response to Therapy}

Considering the limited number of studies assessing the ability of lncRNAs to predict response to therapy in RCC, we decided not to subdivide this section according to sample source. Qu and colleagues analyzed 71 plasma samples from ccRCC patients treated with sunitinib, in which high lncARSR expression levels were found in patients with progressive disease and poor response [204]. In another study, lncRNA Sorafenib Resistance in Renal Cell Carcinoma Associated (lncSRLR) expression was determined in tissue samples from 53 ccRCC patients treated with sorafenib. Patients with poor or no response to sorafenib therapy showed significantly higher expression levels of that lncRNA, which correlated with shorter PFS. In vitro studies revealed that lncSRLR knockdown in sorafenib-resistant RCC cell lines resulted in increased sensitivity to the treatment [205]. Furthermore, studies on RCC cell lines demonstrated a potential positive feedback loop between sunitinib and lncRNA Suppressing Androgen Receptor in Renal Cell Carcinoma (SARCC). Upon treatment with this TKI, lncRNA SARCC expression levels increased, leading to decreased resistance to sunitinib therapy [206]. Finally, a recent study reported that patients with poor response to sorafenib therapy displayed lower IncRNA Growth arrest-specific 5 (GAS5) expression levels. In vitro and in vivo experiments disclosed that overexpression of lncRNA GAS5 resulted in increased sensitivity to sorafenib [207]. Complete information on these studies is summarized in Table 8.

Table 8. Therapy-predictive lncRNAs for RCC in tissue, liquid biopsies, and in vitro studies.

\begin{tabular}{|c|c|c|c|c|c|c|}
\hline Year & $\begin{array}{l}\text { Predictive } \\
\text { Biomarker }\end{array}$ & $\begin{array}{l}\text { Biological } \\
\text { Source }\end{array}$ & $\begin{array}{c}\text { Number of } \\
\text { Cases/Cell Lines }\end{array}$ & $\begin{array}{l}\text { Type of } \\
\text { Therapy }\end{array}$ & Main Findings & Reference \\
\hline 2016 & lncARSR & Plasma & $71 \mathrm{ccRCC}$ & TargetedTherapy & $\begin{array}{l}\uparrow \text { lncARSR in progressive } \\
\text { disease during sunitinib therapy }\end{array}$ & [204] \\
\hline 2017 & $\operatorname{lncSRLR}$ & Tissue/in vitro & $\begin{array}{c}51 \text { RCC; } \\
\text { RCC cell lines }\end{array}$ & TargetedTherapy & $\begin{array}{c}\uparrow \operatorname{lncSRLR} \text { in } \\
\text { sorafenib non-responders. } \\
\text { In vitro ablation } \Rightarrow \uparrow \\
\text { therapeutic sensitivity }\end{array}$ & [205] \\
\hline 2017 & SARCC & In vitro & RCC cell lines & TargetedTherapy & $\begin{array}{c}\uparrow \text { SARCC after } \\
\text { sunitinib treatment } \Rightarrow \downarrow \\
\text { sunitinib resistance } \\
\text { (positive feedback loop) }\end{array}$ & [206] \\
\hline 2019 & GAS5 & $\begin{array}{l}\text { Tissue/ } \\
\text { in vitro/ } \\
\text { in vivo }\end{array}$ & $\begin{array}{l}15 \text { ccRCC; } \\
\text { RCC cell lines; } \\
\text { mice model }\end{array}$ & TargetedTherapy & $\begin{array}{l}\downarrow \text { GAS5 in sorafenib } \\
\text { non-responders; in vitro/ in vivo } \\
\text { re-introduction } \Rightarrow \uparrow \text { sensitivity }\end{array}$ & [207] \\
\hline
\end{tabular}

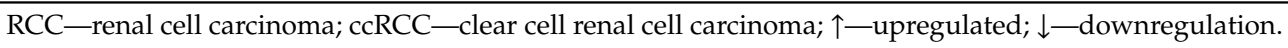

\section{Conclusions}

In summary, the data presented herein clearly support the feasibility of using ncRNAs as RCT biomarkers, both in tissue and liquid biopsies. Importantly, liquid biopsy-based samples are easily collected, minimally invasive, and may help to overcome the limitations of tissue biopsies. Further studies on ncRNAs should focus on technical and clinical validation, preferably using large-scale multicenter cohorts, allowing to determine whether these novel biomarkers may improve the clinical management of RCT patients. Finally, Figure 2 summarizes and illustrates the most promising 
ncRNAs for RCTs' detection, diagnosis, prognostication, and prediction to therapy response included in this review.

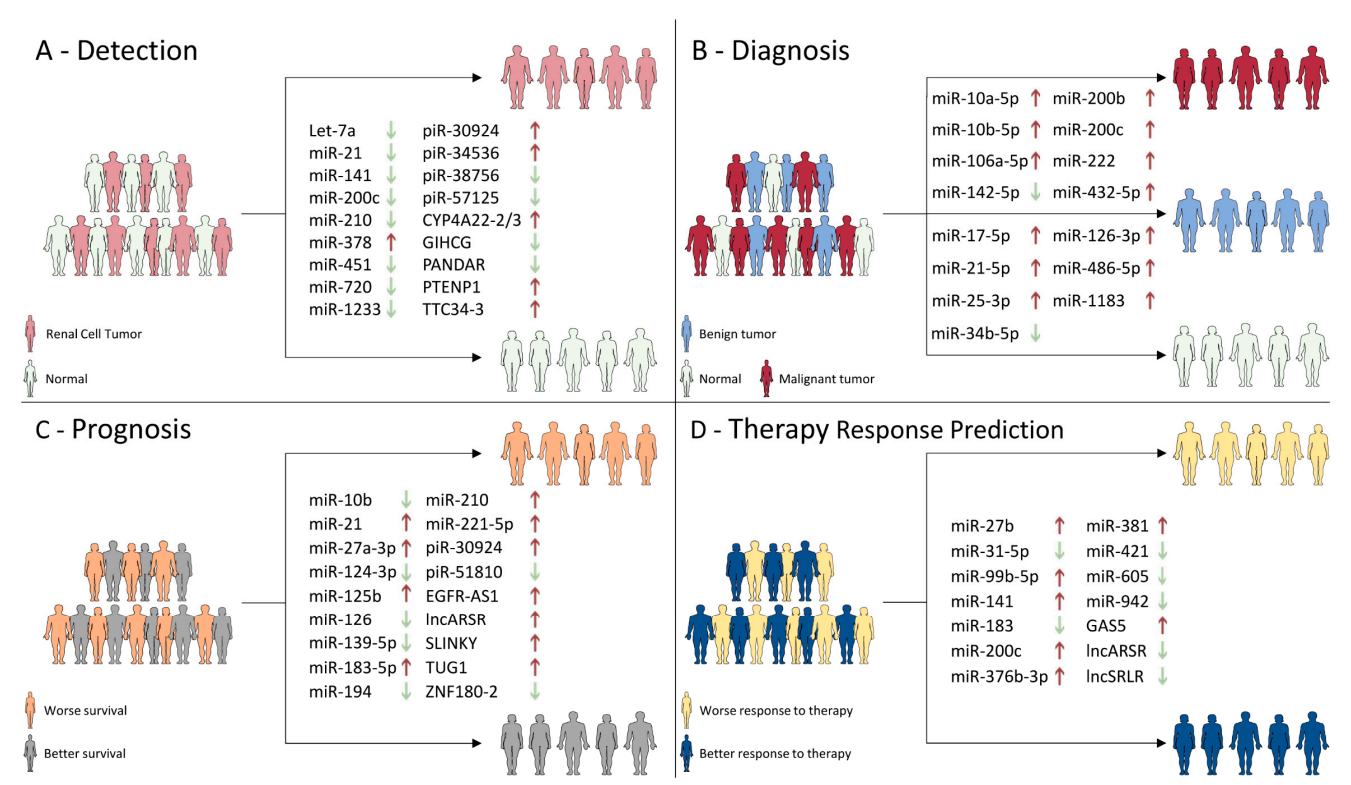

Figure 2. Summary of the most promising biomarker candidates for RCT. (A) Several ncRNAs have been proposed as ancillary tools for distinguishing tumor growth from normal tissue. Arrows represent each ncRNA expression level in RCT, comparing to normal samples ("red"- -upregulated; "green"-downregulated). (B) Besides the potential use of ncRNAs to detect tumorigenesis, some were reported as capable to differentiate both malignant from benign lesions, and benign from asymptomatic conditions. The arrows represent ncRNA expression level (upper) in RCC, comparing to RCT and (lower) renal benign tumors, comparing to normal samples ("red"- upregulated; "green"- downregulated). (C) The potential of ncRNAs to stratify high-risk patients has been highly studied in recent years. The arrows represent each ncRNA expression level in patients displaying worse survival, comparing to those with better survival ("red"—upregulated; "green"—-downregulated). (D) Lastly, ncRNA expression level has been proposed as potential predictor of therapy response. The arrows show the biological status of each ncRNA for a better response to therapy ("red'-upregulated; "green"- downregulated).

Author Contributions: Conceptualization, G.O.-P., D.B.-S., and C.J.; manuscript writing, G.O.-P. and D.B.-S.; critically revising the manuscript, M.P.C., R.H., and C.J.; images were conceptualized and performed by G.O.-P. and M.P.C.; supervision, R.H. and C.J. All authors have read and agreed to the published version of the manuscript.

Funding: This work was funded by Research Center IPO-Porto: PI112-CI-IPOP 92-2018-MCTKidCan and ACCuseD- POCI-01-0145-FEDER-030388. Both D.B.-S. and M.P.C. are funded by FCT-Fundação para a Ciência e Tecnologia: PhD fellowship (SFRH/BD/136007/2018) and contract (CEECINST/00091/2018), respectively.

Conflicts of Interest: The authors declare no conflict of interest. The funders had no role in the design of the study; in the collection, analyses, or interpretation of data; in the writing of the manuscript, or in decision to publish the results.

\section{References}

1. Bray, F.; Ferlay, J.; Soerjomataram, I.; Siegel, R.L.; Torre, L.A.; Jemal, A. Global cancer statistics 2018: GLOBOCAN estimates of incidence and mortality worldwide for 36 cancers in 185 countries. CA Cancer J. Clin. 2018, 68, 394-424. [CrossRef] [PubMed]

2. Maher, E.R. Genomics and epigenomics of renal cell carcinoma. Semin. Cancer Biol. 2013, 23, 10-17. [CrossRef] [PubMed]

3. Moch, H.; Cubilla, A.L.; Humphrey, P.A.; Reuter, V.E.; Ulbright, T.M. The 2016 WHO Classification of Tumours of the Urinary System and Male Genital Organs-Part A: Renal, Penile, and Testicular Tumours. Eur. Urol. 2016, 70, 93-105. [CrossRef] [PubMed] 
4. Capitanio, U.; Bensalah, K.; Bex, A.; Boorjian, S.A.; Bray, F.; Coleman, J.; Gore, J.L.; Sun, M.; Wood, C.; Russo, P. Epidemiology of Renal Cell Carcinoma. Eur. Urol. 2019, 75, 74-84. [CrossRef] [PubMed]

5. Patard, J.-J.; Leray, E.; Rodriguez, A.; Rioux-Leclercq, N.; Guillé, F.; Lobel, B. Correlation between symptom graduation, tumor characteristics and survival in renal cell carcinoma. Eur. Urol. 2003, 44, 226-232. [CrossRef]

6. Ljungberg, B.; Albiges, L.; Abu-Ghanem, Y.; Bensalah, K.; Dabestani, S.; Fernández-Pello, S.; Giles, R.H.; Hofmann, F.; Hora, M.; Kuczyk, M.A.; et al. European Association of Urology Guidelines on Renal Cell Carcinoma: The 2019 Update. Eur. Urol. 2019, 75, 799-810. [CrossRef]

7. Rosenberg, S.A. Interleukin 2 for patients with renal cancer. Nat. Clin. Pract. Oncol. 2007, 4, 497. [CrossRef]

8. Ikarashi, D.; Nakamura, Y.; Shimodate, H.; Usui, Y.; Ujiie, T.; Obara, W. Complete response to perioperative treatment using nivolumab for metastatic renal cell carcinoma: A case report. Urol. Case Rep. 2019, 24, 100839. [CrossRef]

9. Wood, C.; Srivastava, P.; Bukowski, R.; Lacombe, L.; Gorelov, A.I.; Gorelov, S.; Mulders, P.; Zieliński, H.; Hoos, A.; Teofilovici, F.; et al. An adjuvant autologous therapeutic vaccine (HSPPC-96; vitespen) versus observation alone for patients at high risk of recurrence after nephrectomy for renal cell carcinoma: A multicentre, open-label, randomised phase III trial. Lancet 2008, 372, 145-154. [CrossRef]

10. Janowitz, T.; Welsh, S.J.; Zaki, K.; Mulders, P.; Eisen, T. Adjuvant Therapy in Renal Cell Carcinoma-Past, Present, and Future. Semin. Oncol. 2013, 40, 482-491. [CrossRef]

11. Chamie, K.; Donin, N.M.; Klöpfer, P.; Bevan, P.; Fall, B.; Wilhelm, O.; Störkel, S.; Said, J.; Gambla, M.; Hawkins, R.E.; et al. Adjuvant Weekly Girentuximab Following Nephrectomy for High-Risk Renal Cell Carcinoma. JAMA Oncol. 2017, 3, 913-920. [CrossRef] [PubMed]

12. Haas, N.B.; Manola, J.; Dutcher, J.P.; Flaherty, K.T.; Uzzo, R.G.; Atkins, M.B.; DiPaola, R.S.; Choueiri, T.K. Adjuvant Treatment for High-Risk Clear Cell Renal Cancer: Updated Results of a High-Risk Subset of the ASSURE Randomized Trial. JAMA Oncol. 2017, 3, 1249-1252. [CrossRef] [PubMed]

13. Motzer, R.J.; Haas, N.B.; Donskov, F.; Gross-Goupil, M.; Varlamov, S.; Kopyltsov, E.; Lee, J.L.; Melichar, B.; Rini, B.I.; Choueiri, T.K.; et al. Randomized Phase III Trial of Adjuvant Pazopanib Versus Placebo After Nephrectomy in Patients With Localized or Locally Advanced Renal Cell Carcinoma. J. Clin. Oncol. 2017, 35, 3916-3923. [CrossRef] [PubMed]

14. Motzer, R.J.; Ravaud, A.; Patard, J.-J.; Pandha, H.S.; George, D.J.; Patel, A.; Chang, Y.-H.; Escudier, B.; Donskov, F.; Magheli, A.; et al. Adjuvant Sunitinib for High-risk Renal Cell Carcinoma after Nephrectomy: Subgroup Analyses and Updated Overall Survival Results. Eur. Urol. 2017, 73, 62-68. [CrossRef]

15. Patard, J.-J.; Pignot, G.; Escudier, B.; Eisen, T.; Bex, A.; Sternberg, C.; Rini, B.; Roigas, J.; Choueiri, T.; Bukowski, R.; et al. ICUD-EAU International Consultation on Kidney Cancer 2010: Treatment of Metastatic Disease. Eur. Urol. 2011, 60, 684-690. [CrossRef]

16. Motzer, R.J.; Hutson, T.E.; Tomczak, P.; Michaelson, M.D.; Bukowski, R.M.; Rixe, O.; Oudard, S.; Négrier, S.; Szczylik, C.; Kim, S.T.; et al. Sunitinib versus Interferon Alfa in Metastatic Renal-Cell Carcinoma. N. Engl. J. Med. 2007, 356, 115-124. [CrossRef]

17. Choueiri, T.K.; Escudier, B.; Powles, T.; Mainwaring, P.N.; Rini, B.I.; Donskov, F.; Hammers, H.; Hutson, T.E.; Lee, J.-L.; Peltola, K.; et al. Cabozantinib versus Everolimus in Advanced Renal-Cell Carcinoma. N. Engl. J. Med. 2015, 373, 1814-1823. [CrossRef]

18. Ratta, R.; Verzoni, E.; Di Maio, M.; Grassi, P.; Colecchia, M.; Fucà, G.; De Braud, F.; Procopio, G. Exposure to Multiple Lines of Treatment and Survival of Patients With Metastatic Renal Cell Carcinoma: A Real-world Analysis. Clin. Genitourin. Cancer 2018, 16, e735-e742. [CrossRef]

19. Battelli, C.; Cho, D.C. mTOR inhibitors in renal cell carcinoma. Therapy 2011, 8, 359-367. [CrossRef]

20. Motzer, R.J.; Escudier, B.; McDermott, D.F.; George, S.; Hammers, H.J.; Srinivas, S.; Tykodi, S.S.; Sosman, J.A.; Procopio, G.; Plimack, E.R.; et al. Nivolumab versus Everolimus in Advanced Renal-Cell Carcinoma. N. Engl. J. Med. 2015, 373, 1803-1813. [CrossRef]

21. McDermott, D.F.; Sosman, J.A.; Sznol, M.; Massard, C.; Gordon, M.S.; Hamid, O.; Powderly, J.D.; Infante, J.R.; Fassò, M.; Wang, Y.V.; et al. Atezolizumab, an Anti-Programmed Death-Ligand 1 Antibody, in Metastatic Renal Cell Carcinoma: Long-Term Safety, Clinical Activity, and Immune Correlates From a Phase Ia Study. J. Clin. Oncol. 2016, 34, 833-842. [CrossRef] [PubMed]

22. Rini, B.I.; Flaherty, K. Clinical effect and future considerations for molecularly-targeted therapy in renal cell carcinoma. Urol. Oncol. Semin. Orig. Investig. 2008, 26, 543-549. [CrossRef]

23. Esteller, M. Epigenetics in Cancer. N. Engl. J. Med. 2008, 358, 1148-1159. [CrossRef] [PubMed] 
24. Henrique, R.; Luís, A.S.; Jerónimo, C. The Epigenetics of Renal Cell Tumors: From Biology to Biomarkers. Front. Genet. 2012, 3, 94. [CrossRef] [PubMed]

25. Morris, M.R.; Latif, F. The epigenetic landscape of renal cancer. Nat. Rev. Nephrol. 2016, 13, 47-60. [CrossRef]

26. Jerónimo, C.; Henrique, R. Epigenetic biomarkers in urological tumors: A systematic review. Cancer Lett. 2014, 342, 264-274. [CrossRef]

27. Beermann, J.; Piccoli, M.-T.; Viereck, J.; Thum, T. Non-coding RNAs in Development and Disease: Background, Mechanisms, and Therapeutic Approaches. Physiol. Rev. 2016, 96, 1297-1325. [CrossRef]

28. Geisler, S.; Coller, J. RNA in unexpected places: Long non-coding RNA functions in diverse cellular contexts. Nat. Rev. Mol. Cell Boil. 2013, 14, 699-712. [CrossRef]

29. Berezikov, E. Evolution of microRNA diversity and regulation in animals. Nat. Rev. Genet. 2011, 12, 846-860. [CrossRef]

30. Vidigal, J.A.; Ventura, A. The biological functions of miRNAs: Lessons from in vivo studies. Trends Cell Boil. 2014, 25, 137-147. [CrossRef]

31. Kim, V.N.; Han, J.; Siomi, M.C. Biogenesis of small RNAs in animals. Nat. Rev. Mol. Cell Boil. 2009, 10, 126-139. [CrossRef]

32. Czech, B.; Hannon, G. Small RNA sorting: Matchmaking for Argonautes. Nat. Rev. Genet. 2010, $12,19-31$. [CrossRef]

33. Mercer, T.R.; Dinger, M.E.; Mattick, J.W. Long non-coding RNAs: Insights into functions. Nat. Rev. Genet. 2009, 10, 155-159. [CrossRef] [PubMed]

34. Quinn, J.J.; Chang, H.Y. Unique features of long non-coding RNA biogenesis and function. Nat. Rev. Genet. 2015, 17, 47-62. [CrossRef] [PubMed]

35. Grimaldi, A.; Zarone, M.R.; Irace, C.; Zappavigna, S.; Lombardi, A.; Kawasaki, H.; Caraglia, M.; Misso, G. Non-coding RNAs as a new dawn in tumor diagnosis. Semin. Cell Dev. Boil. 2018, 78, 37-50. [CrossRef] [PubMed]

36. Treiber, T.; Treiber, N.; Meister, G. Publisher Correction: Regulation of microRNA biogenesis and its crosstalk with other cellular pathways. Nat. Rev. Mol. Cell Boil. 2019, 20, 321. [CrossRef]

37. Ha, M.; Kim, V.N. Regulation of microRNA biogenesis. Nat. Rev. Mol. Cell Boil. 2014, 15, 509-524. [CrossRef] [PubMed]

38. O'Brien, J.; Hayder, H.; Zayed, Y.; Peng, C. Overview of MicroRNA Biogenesis, Mechanisms of Actions, and Circulation. Front. Endocrinol. 2018, 9, 402. [CrossRef] [PubMed]

39. Aravin, A.A.; Naumova, N.M.; Tulin, A.V.; Vagin, V.V.; Rozovsky, Y.M.; Gvozdev, V. Double-stranded RNA-mediated silencing of genomic tandem repeats and transposable elements in the D. melanogaster germline. Curr. Biol. 2001, 11, 1017-1027. [CrossRef]

40. Vagin, V.V.; Sigova, A.; Li, C.; Gvozdev, V.; Seitz, H.; Zamore, P.D. A Distinct Small RNA Pathway Silences Selfish Genetic Elements in the Germline. Science 2006, 313, 320-324. [CrossRef] [PubMed]

41. Girard, A.; Sachidanandam, R.; Hannon, G.; Carmell, M.A. A germline-specific class of small RNAs binds mammalian Piwi proteins. Nature 2006, 442, 199-202. [CrossRef] [PubMed]

42. Ozata, D.M.; Gainetdinov, I.; Zoch, A.; O'Carroll, D.; Zamore, P.D. PIWI-interacting RNAs: Small RNAs with big functions. Nat. Rev. Genet. 2018, 20, 89-108. [CrossRef] [PubMed]

43. Calin, G.A.; Dumitru, C.D.; Shimizu, M.; Bichi, R.; Zupo, S.; Noch, E.; Aldler, H.; Rattan, S.; Keating, M.; Rai, K.; et al. Frequent deletions and down-regulation of micro- RNA genes miR15 and miR16 at 13q14 in chronic lymphocytic leukemia. Proc. Natl. Acad. Sci. USA 2002, 99, 15524-15529. [CrossRef] [PubMed]

44. The Cancer Genome Atlas Research Network; Cancer Genome Atlas Research Network Comprehensive molecular characterization of clear cell renal cell carcinoma. Nature 2013, 499, 43-49. [CrossRef] [PubMed]

45. Lin, S.; Gregory, R.I. MicroRNA biogenesis pathways in cancer. Nat. Rev. Cancer 2015, 15, 321-333. [CrossRef]

46. Guil, S.; Esteller, M. DNA methylomes, histone codes and miRNAs: Tying it all together. Int. J. Biochem. Cell Biol. 2009, 41, 87-95. [CrossRef]

47. Takamizawa, J.; Chamoto, K.; Tsuji, T.; Funamoto, H.; Kosaka, A.; Matsuzaki, J.; Sato, T.; Konishi, H.; Fujio, K.; Yamamoto, K.; et al. Reduced Expression of the let-7 MicroRNAs in Human Lung Cancers in Association with Shortened Postoperative Survival. Cancer Res. 2004, 64, 3753-3756. [CrossRef]

48. Nakajima, G.; Hayashi, K.; Xi, Y.; Kudo, K.; Uchida, K.; Takasaki, K.; Yamamoto, M.; Ju, J. Non-coding MicroRNAs hsa-let-7g and hsa-miR-181b are Associated with Chemoresponse to S-1 in Colon Cancer. Cancer Genom. Proteom. 2006, 3, 317-324. 
49. Cheng, Y.; Wang, Q.; Jiang, W.; Bian, Y.; Zhou, Y.; Gou, A.; Zhang, W.; Fu, K.; Shi, W. Emerging roles of piRNAs in cancer: Challenges and prospects. Aging 2019, 11, 9932-9946. [CrossRef]

50. Yu, Y.; Xiao, J.; Hann, S.S. The emerging roles of PIWI-interacting RNA in human cancers. Cancer Manag. Res. 2019, 11, 5895-5909. [CrossRef]

51. Busch, J.; Ralla, B.; Jung, M.; Wotschofsky, Z.; Trujillo-Arribas, E.; Schwabe, P.; Kilic, E.; Fendler, A.; Jung, K. Piwi-interacting RNAs as novel prognostic markers in clear cell renal cell carcinomas. J. Exp. Clin. Cancer Res. 2015, 34, 61. [CrossRef] [PubMed]

52. Li, Y.; Wu, X.; Gao, H.; Jin, J.M.; Li, A.X.; Kim, Y.S.; Pal, S.K.; Nelson, R.A.; Lau, C.M.; Guo, C.; et al. Piwi-Interacting RNAs (piRNAs) Are Dysregulated in Renal Cell Carcinoma and Associated with Tumor Metastasis and Cancer-Specific Survival. Mol. Med. 2015, 21, 381-388. [CrossRef] [PubMed]

53. Iliev, R.; Fedorko, M.; Machackova, T.; Mlcochova, H.; Svoboda, M.; Pacik, D.; Dolezel, J.; Stanik, M.; Capoor, M.N. Expression Levels of PIWI-interacting RNA, piR-823, Are Deregulated in Tumor Tissue, Blood Serum and Urine of Patients with Renal Cell Carcinoma. Anticancer. Res. 2016, 36, 6419-6424. [CrossRef] [PubMed]

54. Wotschofsky, Z.; Busch, J.; Jung, M.; Kempkensteffen, C.; Weikert, S.; Schaser, K.D.; Melcher, I.; Kilic, E.; Miller, K.; Kristiansen, G.; et al. Diagnostic and prognostic potential of differentially expressed miRNAs between metastatic and non-metastatic renal cell carcinoma at the time of nephrectomy. Clin. Chim. Acta 2013, 416, 5-10. [CrossRef]

55. Silva-Santos, R.M.; Costa-Pinheiro, P.; Luis, A.; Antunes, L.; Lobo, F.; Oliveira, J.; Henrique, R.; Jerónimo, C. MicroRNA profile: A promising ancillary tool for accurate renal cell tumour diagnosis. Br. J. Cancer 2013, 109, 2646-2653. [CrossRef]

56. Jung, M.; Mollenkopf, H.-J.; Grimm, C.H.; Wagner, I.; Albrecht, M.; Waller, T.; Pilarsky, C.; Johannsen, M.; Stephan, C.; Lehrach, H.; et al. MicroRNA profiling of clear cell renal cell cancer identifies a robust signature to define renal malignancy. J. Cell. Mol. Med. 2009, 13, 3918-3928. [CrossRef]

57. Fridman, E.; Dotan, Z.; Barshack, I.; Ben David, M.; Dov, A.; Tabak, S.; Zion, O.; Benjamin, S.; Benjamin, H.; Kuker, H.; et al. Accurate Molecular Classification of Renal Tumors Using MicroRNA Expression. J. Mol. Diagn. 2010, 12, 687-696. [CrossRef]

58. Faragalla, H.; Youssef, Y.M.; Scorilas, A.; Khalil, B.; White, N.M.; Mejia-Guerrero, S.; Khella, H.; Jewett, M.A.; Evans, A.; Lichner, Z.; et al. The Clinical Utility of miR-21 as a Diagnostic and Prognostic Marker for Renal Cell Carcinoma. J. Mol. Diagn. 2012, 14, 385-392. [CrossRef]

59. Wach, S.; Nolte, E.; Theil, A.; Stöhr, C.; Rau, T.T.; Hartmann, A.; Ekici, A.; Keck, B.; Taubert, H.; Wullich, B. MicroRNA profiles classify papillary renal cell carcinoma subtypes. Br. J. Cancer 2013, 109, 714-722. [CrossRef]

60. Zaravinos, A.; Lambrou, G.I.; Mourmouras, N.; Katafygiotis, P.; Papagregoriou, G.; Giannikou, K.; Delakas, D.; Deltas, C. New miRNA Profiles Accurately Distinguish Renal Cell Carcinomas and Upper Tract Urothelial Carcinomas from the Normal Kidney. PLoS ONE 2014, 9, e91646. [CrossRef]

61. Chen, X.; Wang, X.; Ruan, A.; Han, W.; Zhao, Y.; Lu, X.; Xiao, P.; Shi, H.; Wang, R.; Chen, L.; et al. miR-141 Is a Key Regulator of Renal Cell Carcinoma Proliferation and Metastasis by Controlling EphA2 Expression. Clin. Cancer Res. 2014, 20, 2617-2630. [CrossRef] [PubMed]

62. Chen, X.; Ruan, A.; Wang, X.; Han, W.; Wang, R.; Lou, N.; Ruan, H.; Qiu, B.; Yang, H.; Zhang, X. miR-129-3p, as a diagnostic and prognostic biomarker for renal cell carcinoma, attenuates cell migration and invasion via downregulating multiple metastasis-related genes. J. Cancer Res. Clin. Oncol. 2014, 140, 1295-1304. [CrossRef] [PubMed]

63. Vergho, D.; Kneitz, S.; Kalogirou, C.; Burger, M.; Krebs, M.; Rosenwald, A.; Spahn, M.; Löser, A.; Kocot, A.; Riedmiller, H.; et al. Impact of miR-21, miR-126 and miR-221 as Prognostic Factors of Clear Cell Renal Cell Carcinoma with Tumor Thrombus of the Inferior Vena Cava. PLoS ONE 2014, 9, e109877. [CrossRef] [PubMed]

64. Papadopoulos, E.I.; Petraki, C.; Gregorakis, A.; Fragoulis, E.G.; Scorilas, A. Clinical evaluation of microRNA-145 expression in renal cell carcinoma: A promising molecular marker for discriminating and staging the clear cell histological subtype. Boil. Chem. 2016, 397, 529-539. [CrossRef]

65. Liep, J.; Kilic, E.; Meyer, H.A.; Busch, J.; Jung, K.; Rabien, A. Cooperative Effect of miR-141-3p and miR-145-5p in the Regulation of Targets in Clear Cell Renal Cell Carcinoma. PLoS ONE 2016, 11, e0157801. [CrossRef] [PubMed]

66. Kowalik, C.G.; Palmer, D.A.; Sullivan, T.B.; Teebagy, P.A.; Dugan, J.M.; Libertino, J.A.; Burks, E.J.; Canes, D.; Rieger-Christ, K.M. Profiling microRNA from nephrectomy and biopsy specimens: Predictors of progression and survival in clear cell renal cell carcinoma. BJU Int. 2017, 120, 428-440. [CrossRef] 
67. Toraih, E.A.; Ibrahiem, A.T.; Fawzy, M.S.; Hussein, M.H.; Al-Qahtani, S.A.M.; Shaalan, A.A.M. MicroRNA-34a: A Key Regulator in the Hallmarks of Renal Cell Carcinoma. Oxidative Med. Cell. Longev. 2017, 2017, 1-21. [CrossRef]

68. Di Meo, A.; Saleeb, R.; Wala, S.J.; Khella, H.W.; Ding, Q.; Zhai, H.; Krishan, K.; Krizova, A.; Gabril, M.; Evans, A.; et al. A miRNA-based classification of renal cell carcinoma subtypes by PCR and in situ hybridization. Oncotarget 2017, 9, 2092-2104. [CrossRef]

69. Yadav, S.; Khandelwal, M.; Seth, A.; Saini, A.; Dogra, P.N.; Sharma, A. Serum microRNA Expression Profiling: Potential Diagnostic Implications of a Panel of Serum microRNAs for Clear Cell Renal Cell Cancer. Urology 2017, 104, 64-69. [CrossRef]

70. Bhat, N.S.; Colden, M.; Dar, A.A.; Saini, S.; Arora, P.; Shahryari, V.; Yamamura, S.; Tanaka, Y.; Kato, T.; Majid, S.; et al. MicroRNA-720 Regulates E-cadherin-alphaE-catenin Complex and Promotes Renal Cell Carcinoma. Mol. Cancer Ther. 2017, 16, 2840-2848. [CrossRef]

71. Dasgupta, P.; Kulkarni, P.; Majid, S.; Shahryari, V.; Hashimoto, Y.; Bhat, N.S.; Shiina, M.; Deng, G.; Saini, S.; Tabatabai, Z.L.; et al. MicroRNA-203 Inhibits Long Noncoding RNA HOTAIR and Regulates Tumorigenesis through Epithelial-to-mesenchymal Transition Pathway in Renal Cell Carcinoma. Mol. Cancer Ther. 2018, 17, 1061-1069. [CrossRef] [PubMed]

72. Kulkarni, P.; Dasgupta, P.; Bhat, N.S.; Shahryari, V.; Shiina, M.; Hashimoto, Y.; Majid, S.; Deng, G.; Saini, S.; Tabatabai, Z.L.; et al. Elevated miR-182-5p Associates with Renal Cancer Cell Mitotic Arrest through Diminished MALAT-1 Expression. Mol. Cancer Res. 2018, 16, 1750-1760. [CrossRef] [PubMed]

73. Chen, X.; Lou, N.; Ruan, A.; Qiu, B.; Yan, Y.; Wang, X.; Du, Q.; Ruan, H.; Han, W.; Wei, H.; et al. $\mathrm{miR}-224 / \mathrm{miR}-141$ ratio as a novel diagnostic biomarker in renal cell carcinoma. Oncol. Lett. 2018, 16, 1666-1674. [CrossRef] [PubMed]

74. Zhai, W.; Li, S.; Zhang, J.; Chen, Y.; Ma, J.; Kong, W.; Gong, D.; Zheng, J.; Xue, W.; Xu, Y. Sunitinib-suppressed miR-452-5p facilitates renal cancer cell invasion and metastasis through modulating SMAD4/SMAD7 signals. Mol. Cancer 2018, 17, 157. [CrossRef] [PubMed]

75. Zhao, C.; Tolkach, Y.; Schmidt, D.; Toma, M.; Muders, M.H.; Kristiansen, G.; Müller, S.C.; Ellinger, J. Mitochondrial PIWI-interacting RNAs are novel biomarkers for clear cell renal cell carcinoma. World J. Urol. 2018, 37, 1639-1647. [CrossRef]

76. Li, J.; Chen, C.; Shi, Z. The biological roles and clinical implications of microRNAs in clear cell renal cell carcinoma. J. Cell. Physiol. 2017, 233, 4458-4465. [CrossRef]

77. Wulfken, L.M.; Moritz, R.; Ohlmann, C.; Holdenrieder, S.; Jung, V.; Becker, F.; Herrmann, E.; Walgenbach-Brünagel, G.; Von Ruecker, A.; Müller, S.C.; et al. MicroRNAs in Renal Cell Carcinoma: Diagnostic Implications of Serum miR-1233 Levels. PLoS ONE 2011, 6, e25787. [CrossRef]

78. Zhao, A.; Li, G.; Péoc'H, M.; Genin, C.; Gigante, M. Serum miR-210 as a novel biomarker for molecular diagnosis of clear cell renal cell carcinoma. Exp. Mol. Pathol. 2013, 94, 115-120. [CrossRef]

79. Zhang, W.; Ni, M.; Su, Y.; Wang, H.; Zhu, S.; Zhao, A.; Li, G. MicroRNAs in Serum Exosomes as Potential Biomarkers in Clear-cell Renal Cell Carcinoma. Eur. Urol. Focus 2018, 4, 412-419. [CrossRef]

80. Tusong, H.; Maolakuerban, N.; Guan, J.; Rexiati, M.; Wang, W.-G.; Azhati, B.; Nuerrula, Y.; Wang, Y.-J. Functional analysis of serum microRNAs miR-21 and miR-106a in renal cell carcinoma. Cancer Biomark. 2017, 18, 79-85. [CrossRef]

81. Lou, N.; Ruan, A.-M.; Qiu, B.; Bao, L.; Xu, Y.-C.; Zhao, Y.; Sun, R.-L.; Zhang, S.-T.; Xu, G.-H.; Ruan, H.-L.; et al. miR-144-3p as a novel plasma diagnostic biomarker for clear cell renal cell carcinoma. Urol. Oncol. 2017, 35, 36.e7. [CrossRef] [PubMed]

82. Butz, H.; Nofech-Mozes, R.; Ding, Q.; Khella, H.W.; Szabó, P.M.; Jewett, M.; Finelli, A.; Lee, J.; Ordon, M.; Stewart, R.; et al. Exosomal MicroRNAs Are Diagnostic Biomarkers and Can Mediate Cell-Cell Communication in Renal Cell Carcinoma. Eur. Urol. Focus 2016, 2, 210-218. [CrossRef] [PubMed]

83. Mytsyk, Y.; Dosenko, V.; Borys, Y.; Kucher, A.; Gazdikova, K.; Büsselberg, D.; Caprnda, M.; Kruzliak, P.; Farooqi, A.A.; Lubov, M. MicroRNA-15a expression measured in urine samples as a potential biomarker of renal cell carcinoma. Int. Urol. Nephrol. 2018, 50, 851-859. [CrossRef] [PubMed]

84. Redova, M.; Poprach, A.; Nekvindova, J.; Iliev, R.; Radova, L.; Lakomy, R.; Svoboda, M.; Vyzula, R.; Slaby, O. Circulating miR-378 and miR-451 in serum are potential biomarkers for renal cell carcinoma. J. Transl. Med. 2012, 10, 55. [CrossRef] 
85. Iwamoto, H.; Kanda, Y.; Sejima, T.; Osaki, M.; Okada, F.; Takenaka, A. Serum miR-210 as a potential biomarker of early clear cell renal cell carcinoma. Int. J. Oncol. 2013, 44, 53-58. [CrossRef]

86. Teixeira, A.L.; Ferreira, M.; Silva, J.; Gomes, M.; Dias, F.; Santos, J.I.; Maurício, J.; Lobo, F.; Medeiros, R. Higher circulating expression levels of miR-221 associated with poor overall survival in renal cell carcinoma patients. Tumor Boil. 2013, 35, 4057-4066. [CrossRef]

87. Wang, C.; Hu, J.; Lu, M.; Gu, H.; Zhou, X.; Chen, X.; Zen, K.; Zhang, C.-Y.; Zhang, T.; Ge, J.; et al. A panel of five serum miRNAs as a potential diagnostic tool for early-stage renal cell carcinoma. Sci. Rep. 2015, 5, 7610. [CrossRef]

88. Fedorko, M.; Stanik, M.; Iliev, R.; Rédová-Lojová, M.; Machackova, T.; Svoboda, M.; Pacík, D.; Dolezel, J.; Slaby, O. Combination of MiR-378 and MiR-210 Serum Levels Enables Sensitive Detection of Renal Cell Carcinoma. Int. J. Mol. Sci. 2015, 16, 23382-23389. [CrossRef]

89. Li, G.; Zhao, A.; Péoch, M.; Cottier, M.; Mottet, N. Detection of urinary cell-free miR-210 as a potential tool of liquid biopsy for clear cell renal cell carcinoma. Urol. Oncol. Semin. Orig. Investig. 2017, 35, 294-299. [CrossRef]

90. Fedorko, M.; Juracek, J.; Stanik, M.; Svoboda, M.; Poprach, A.; Buchler, T.; Pacik, D.; Dolezel, J.; Slaby, O. Detection of let-7 miRNAs in urine supernatant as potential diagnostic approach in non-metastatic clear-cell renal cell carcinoma. Biochem. Med. 2017, 27, 411-417. [CrossRef]

91. Chanudet, E.; Wozniak, M.B.; Bouaoun, L.; Byrnes, G.B.; Mukeria, A.; Zaridze, D.G.; Brennan, P.; Muller, D.C.; Scelo, G. Large-scale genome-wide screening of circulating microRNAs in clear cell renal cell carcinoma reveals specific signatures in late-stage disease. Int. J. Cancer 2017, 141, 1730-1740. [CrossRef] [PubMed]

92. Wang, X.; Wang, T.; Chen, C.; Wu, Z.; Bai, P.; Li, S.; Chen, B.; Liu, R.; Zhang, K.; Li, W.; et al. Serum exosomal miR-210 as a potential biomarker for clear cell renal cell carcinoma. J. Cell. Biochem. 2018, 120, 1492-1502. [CrossRef] [PubMed]

93. Liu, S.; Deng, X.; Zhang, J. Identification of dysregulated serum miR-508-3p and miR-885-5p as potential diagnostic biomarkers of clear cell renal carcinoma. Mol. Med. Rep. 2019, 20, 5075-5083. [CrossRef] [PubMed]

94. Di Meo, A.; Brown, M.D.; Finelli, A.; Jewett, M.A.; Diamandis, E.P.; Mac-Way, F. Prognostic urinary miRNAs for the assessment of small renal masses. Clin. Biochem. 2019, 75, 15-22. [CrossRef]

95. Outeiro-Pinho, G.; Barros-Silva, D.; Aznar, E.; Sousa, A.-I.; Vieira-Coimbra, M.; Oliveira, J.; Gonçalves, C.S.; Costa, B.M.; Junker, K.; Henrique, R.; et al. MicroRNA-30a-5p(me): A novel diagnostic and prognostic biomarker for clear cell renal cell carcinoma in tissue and urine samples. J. Exp. Clin. Cancer Res. 2020, $39,98$. [CrossRef]

96. Wang, G.; Chen, L.; Meng, J.; Chen, M.; Zhuang, L.; Zhang, L. Overexpression of microRNA-100 predicts an unfavorable prognosis in renal cell carcinoma. Int. Urol. Nephrol. 2013, 45, 373-379. [CrossRef]

97. Zhao, J.-J.; Chen, P.-J.; Duan, R.-Q.; Li, K.-J.; Wang, Y.-Z.; Li, Y. Up-regulation of miR-630 in clear cell renal cell carcinoma is associated with lower overall survival. Int. J. Clin. Exp. Pathol. 2014, 7, 3318-3323.

98. Samaan, S.; Khella, H.W.; Girgis, A.; Scorilas, A.; Lianidou, E.; Gabril, M.; Krylov, S.N.; Jewett, M.; Bjarnason, G.A.; El-Said, H.; et al. miR-210 Is a Prognostic Marker in Clear Cell Renal Cell Carcinoma. J. Mol. Diagn. 2015, 17, 136-144. [CrossRef]

99. Dias, F.; Teixeira, A.; Ferreira, M.; Adem, B.; Bastos, N.; Vieira, J.; Fernandes, M.; Sequeira, M.I.; Maurício, J.; Lobo, F.; et al. Plasmatic miR-210, miR-221 and miR-1233 profile: Potential liquid biopsies candidates for renal cell carcinoma. Oncotarget 2017, 8, 103315-103326. [CrossRef]

100. Zhang, J.; Ye, Y.; Chang, D.W.; Lin, S.-H.; Huang, M.; Tannir, N.M.; Matin, S.; Karam, J.A.; Wood, C.G.; Chen, Z.-N.; et al. Global and Targeted miRNA Expression Profiling in Clear Cell Renal Cell Carcinoma Tissues Potentially Links miR-155-5p and miR-210-3p to both Tumorigenesis and Recurrence. Am. J. Pathol. 2018, 188, 2487-2496. [CrossRef]

101. McCormick, R.I.; Blick, C.; Ragoussis, J.; Schoedel, J.; Mole, D.R.; Young, A.C.; Selby, P.J.; Banks, R.; Harris, A.L. miR-210 is a target of hypoxia-inducible factors 1 and 2 in renal cancer, regulates ISCU and correlates with good prognosis. Br. J. Cancer 2013, 108, 1133-1142. [CrossRef] [PubMed]

102. Nakata, W.; Uemura, M.; Sato, M.; Fujita, K.; Jingushi, K.; Ueda, Y.; Kitae, K.; Tsujikawa, K.; Nonomura, N. Expression of miR-27a-3p is an independent predictive factor for recurrence in clear cell renal cell carcinoma. Oncotarget 2015, 6, 21645-21654. [CrossRef] [PubMed]

103. Shinmei, S.; Sakamoto, N.; Goto, K.; Sentani, K.; Anami, K.; Hayashi, T.; Teishima, J.; Matsubara, A.; Oue, N.; Kitadai, Y.; et al. MicroRNA-155 is a predictive marker for survival in patients with clear cell renal cell carcinoma. Int. J. Urol. 2012, 20, 468-477. [CrossRef] [PubMed] 
104. Hildebrandt, M.A.T.; Gu, J.; Lin, J.; Ye, Y.; Tan, W.; Tamboli, P.; Wood, C.G.; Wu, X. Hsa-miR-9 methylation status is associated with cancer development and metastatic recurrence in patients with clear cell renal cell carcinoma. Oncogene 2010, 29, 5724-5728. [CrossRef]

105. Wu, X.; Weng, L.; Li, X.; Guo, C.; Pal, S.K.; Jin, J.M.; Li, Y.; Nelson, R.A.; Mu, B.; Onami, S.H.; et al. Identification of a 4-microRNA Signature for Clear Cell Renal Cell Carcinoma Metastasis and Prognosis. PLOS ONE 2012, 7, e35661. [CrossRef]

106. Gebauer, K.; Peters, I.; Dubrowinskaja, N.; Hennenlotter, J.; Abbas, M.; Scherer, R.; Tezval, H.; Merseburger, A.S.; Stenzl, A.; A Kuczyk, M.; et al. Hsa-mir-124-3 CpG island methylation is associated with advanced tumours and disease recurrence of patients with clear cell renal cell carcinoma. Br. J. Cancer 2013, 108, 131-138. [CrossRef]

107. Goto, K.; Oue, N.; Shinmei, S.; Sentani, K.; Sakamoto, N.; Naito, Y.; Hayashi, T.; Teishima, J.; Matsubara, A.; Yasui, W. Expression of miR-486 is a potential prognostic factor after nephrectomy in advanced renal cell carcinoma. Mol. Clin. Oncol. 2012, 1, 235-240. [CrossRef]

108. Vergho, D.C.; Kneitz, S.; Rosenwald, A.; Scherer, C.; Spahn, M.; Burger, M.; Riedmiller, H.; Kneitz, B. Combination of expression levels of miR-21 and miR-126 is associated with cancer-specific survival in clear-cell renal cell carcinoma. BMC Cancer 2014, 14, 25. [CrossRef]

109. Fritz, H.K.; Lindgren, D.; Ljungberg, B.; Axelson, H.; Dahlbäck, B. The miR(21/10b) ratio as a prognostic marker in clear cell renal cell carcinoma. Eur. J. Cancer 2014, 50, 1758-1765. [CrossRef]

110. Fu, Q.; Liu, Z.; Pan, D.; Zhang, W.; Xu, L.; Zhu, Y.; Liu, H.; Xu, J. Tumor miR-125b predicts recurrence and survival of patients with clear-cell renal cell carcinoma after surgical resection. Cancer Sci. 2014, 105, 1427-1434. [CrossRef]

111. Zhao, X.; Zhao, Z.; Xu, W.; Hou, J.; Du, X. Down-regulation of miR-497 is associated with poor prognosis in renal cancer. Int. J. Clin. Exp. Pathol. 2015, 8, 758-764. [PubMed]

112. Khella, H.W.; Scorilas, A.; Mozes, R.; Mirham, L.; Lianidou, E.; Krylov, S.N.; Lee, J.Y.; Ordon, M.; Stewart, R.; Jewett, M.A.; et al. Low Expression of miR-126 Is a Prognostic Marker for Metastatic Clear Cell Renal Cell Carcinoma. Am. J. Pathol. 2015, 185, 693-703. [CrossRef] [PubMed]

113. Yang, F.-Q.; Zhang, H.-M.; Chen, S.-J.; Yan, Y.; Zheng, J.-H. MiR-506 is down-regulated in clear cell renal cell carcinoma and inhibits cell growth and metastasis via targeting FLOT. PLoS ONE 2015, 10, e0120258.

114. Xu, M.; Gu, M.; Zhang, K.; Zhou, J.; Wang, Z.; Da, J. miR-203 inhibition of renal cancer cell proliferation, migration and invasion by targeting of FGF. Diagn. Pathol. 2015, 10, 24. [CrossRef]

115. Tang, K.; Xu, H. Prognostic value of meta-signature miRNAs in renal cell carcinoma: An integrated miRNA expression profiling analysis. Sci. Rep. 2015, 5, 10272. [CrossRef]

116. Butz, H.; Szabó, P.M.; Khella, H.W.; Nofech-Mozes, R.; Patócs, A.; Mac-Way, F. miRNA-target network reveals miR-124as a key miRNA contributing to clear cell renal cell carcinoma aggressive behaviour by targeting CAV1 and FLOT. Oncotarget 2015, 6, 12543-12557. [CrossRef]

117. Nofech-Mozes, R.; Khella, H.W.Z.; Scorilas, A.; Youssef, L.; Krylov, S.N.; Lianidou, E.; Sidiropoulos, K.G.; Gabril, M.; Evans, A.; Mac-Way, F. MicroRNA-194 is a Marker for Good Prognosis in Clear Cell Renal Cell Carcinoma. Cancer Med. 2016, 5, 656-664. [CrossRef]

118. Ma, Q.; Peng, Z.; Wang, L.; Li, Y.; Wang, K.; Zheng, J.; Liang, Z.; Liu, T. miR-19a correlates with poor prognosis of clear cell renal cell carcinoma patients via promoting cell proliferation and suppressing PTEN/SMAD4 expression. Int. J. Oncol. 2016, 49, 2589-2599. [CrossRef]

119. García-Donás, J.; Beuselinck, B.; Inglada-Pérez, L.; Castro, O.G.; Schöffski, P.; Wozniak, A.; Bechter, O.; Apellániz-Ruiz, M.; Leandro-García, L.J.; Esteban, E.; et al. Deep sequencing reveals microRNAs predictive of antiangiogenic drug response. JCI Insight 2016, 1, e86051. [CrossRef]

120. Khella, H.W.Z.; Daniel, N.; Youssef, L.; Scorilas, A.; Nofech-Mozes, R.; Mirham, L.; Krylov, S.N.; Liandeau, E.; Krizova, A.; Finelli, A.; et al. miR-10b is a prognostic marker in clear cell renal cell carcinoma. J. Clin. Pathol. 2017, 70, 854-859. [CrossRef]

121. Chen, C.; Xue, S.; Zhang, J.; Chen, W.; Gong, D.; Zheng, J.; Ma, J.; Xue, W.; Chen, Y.; Zhai, W.; et al. DNA-methylation-mediated repression of miR-766-3p promotes cell proliferation via targeting SF2 expression in renal cell carcinoma. Int. J. Cancer 2017, 141, 1867-1878. [CrossRef] [PubMed]

122. Pan, X.; Quan, J.; Li, Z.; Zhao, L.; Zhou, L.; Jinling, X.; Weijie, X.; Guan, X.; Li, H.; Yang, S.; et al. miR-566 functions as an oncogene and a potential biomarker for prognosis in renal cell carcinoma. Biomed. Pharmacother. 2018, 102, 718-727. [CrossRef] [PubMed] 
123. Zhou, L.; Li, Z.; Pan, X.; Lai, Y.; Quan, J.; Zhao, L.; Xu, J.; Xu, W.; Guan, X.; Li, H.; et al. Identification of miR-18a-5p as an oncogene and prognostic biomarker in RCC. Am. J. Transl. Res. 2018, 10, 1874-1886. [PubMed]

124. Zhou, L.; Pan, X.; Li, Z.; Chen, P.; Quan, J.; Lin, C.; Lai, Y.; Xu, J.; Xu, W.; Guan, X.; et al. Oncogenic miR-663a is associated with cellular function and poor prognosis in renal cell carcinoma. Biomed. Pharmacother. 2018, 105, 1155-1163. [CrossRef]

125. Pan, X.; Li, Z.; Zhao, L.; Quan, J.; Zhou, L.; Xu, J.; Xu, W.; Guan, X.; Li, H.; Yang, S.; et al. microRNA-572 functions as an oncogene and a potential biomarker for renal cell carcinoma prognosis. Oncol. Rep. 2018, 40, 3092-3101. [CrossRef]

126. Quan, J.; Pan, X.; Li, Y.; Hu, Y.; Tao, L.; Li, Z.; Zhao, L.; Wang, J.; Li, H.; Lai, Y.; et al. MiR-23a-3p acts as an oncogene and potential prognostic biomarker by targeting PNRC2 in RCC. Biomed. Pharmacother. 2019, 110, 656-666. [CrossRef]

127. Li, H.; Pan, X.; Gui, Y.; Quan, J.; Li, Z.; Zhao, L.; Guan, X.; Xu, J.; Xu, W.; Lai, Y. Upregulation of miR-183-5p predicts worse survival in patients with renal cell cancer after surgery. Cancer Biomark. 2019, 24, 153-158. [CrossRef]

128. Chen, X. Expression of microRNA-3133 correlates with the prognosis in patients with clear cell renal cell carcinoma. Medicine 2019, 98, e16008. [CrossRef]

129. Liu, S.; Wang, Y.; Li, W.; Yu, S.; Wen, Z.; Chen, Z.; Lin, F. miR-221-5p acts as an oncogene and predicts worse survival in patients of renal cell cancer. Biomed. Pharmacother. 2019, 119, 109406. [CrossRef]

130. Peng, X.; Pan, X.; Liu, K.; Zhang, C.; Zhao, L.; Li, H.; Guan, X.; Xu, W.; Xu, J.; Zhang, F.; et al. miR-142-3p as a novel biomarker for predicting poor prognosis in renal cell carcinoma patients after surgery. Int. J. Biol. Markers 2019, 34, 302-308. [CrossRef]

131. Liu, K.; Pan, X.; Peng, X.; Zhang, C.; Li, H.; Guan, X.; Xu, W.; Xu, J.; Zhao, L.; Wang, T.; et al. Associations of high expression of miR-106b-5p detected from FFPE sample with poor prognosis of RCC patients. Pathol. Res. Pract. 2019, 215, 152391. [CrossRef] [PubMed]

132. Heinzelmann, J.; Arndt, M.; Pleyers, R.; Fehlmann, T.; Hoelters, S.; Zeuschner, P.; Vogt, A.; Pryalukhin, A.; Schaeffeler, E.; Bohle, R.M.; et al. 4-miRNA Score Predicts the Individual Metastatic Risk of Renal Cell Carcinoma Patients. Ann. Surg. Oncol. 2019, 26, 3765-3773. [CrossRef] [PubMed]

133. Du, M.; Giridhar, K.V.; Tian, Y.; Tschannen, M.R.; Zhu, J.; Huang, C.-C.; Kilari, D.; Kohli, M.; Wang, L. Plasma exosomal miRNAs-based prognosis in metastatic kidney cancer. Oncotarget 2017, 8, 63703-63714. [CrossRef]

134. Fujii, N.; Hirata, H.; Ueno, K.; Mori, J.; Oka, S.; Shimizu, K.; Kawai, Y.; Inoue, R.; Yamamoto, Y.; Matsumoto, H.; et al. Extracellular miR-224 as a prognostic marker for clear cell renal cell carcinoma. Oncotarget 2017, 8, 109877-109888. [CrossRef] [PubMed]

135. Heinemann, F.G.; Tolkach, Y.; Deng, M.; Schmidt, D.; Perner, S.; Kristiansen, G.; Müller, S.; Ellinger, J. Serum miR-122-5p and miR-206 expression: Non-invasive prognostic biomarkers for renal cell carcinoma. Clin. Epigenetics 2018, 10, 11. [CrossRef]

136. Schwandt, A.; Wood, L.S.; Rini, B.; Dreicer, R. Management of side effects associated with sunitinib therapy for patients with renal cell carcinoma. OncoTargets Ther. 2009, 2, 51-61.

137. Eisen, T.; Sternberg, C.N.; Robert, C.; Mulders, P.; Pyle, L.; Zbinden, S.; Izzedine, H.; Escudier, B. Targeted Therapies for Renal Cell Carcinoma: Review of Adverse Event Management Strategies. J. Natl. Cancer Inst. 2012, 104, 93-113. [CrossRef]

138. Makhov, P.; Joshi, S.; Ghatalia, P.; Kutikov, A.; Uzzo, R.; Kolenko, V.M. Resistance to Systemic Therapies in Clear Cell Renal Cell Carcinoma: Mechanisms and Management Strategies. Mol. Cancer Ther. 2018, 17, 1355-1364. [CrossRef]

139. Institute, N.C. Precision Medicine in Cancer Treatment. 3 October 2017. Available online: https://www. cancer.gov/about-cancer/treatment/types/precision-medicine (accessed on 1 April 2020).

140. Corrà, F.; Agnoletto, C.; Minotti, L.; Baldassari, F.; Volinia, S. The Network of Non-coding RNAs in Cancer Drug Resistance. Front. Oncol. 2018, 8, 327. [CrossRef]

141. Wang, W.-T.; Han, C.; Sun, Y.-M.; Chen, T.-Q.; Chen, Y.-Q. Noncoding RNAs in cancer therapy resistance and targeted drug development. J. Hematol. Oncol. 2019, 12, 55. [CrossRef]

142. Zhang, X.; Xie, K.; Zhou, H.; Wu, Y.; Li, C.; Liu, Y.; Liu, Z.; Xu, Q.; Liu, S.; Xiao, D.; et al. Role of non-coding RNAs and RNA modifiers in cancer therapy resistance. Mol. Cancer 2020, 19, 1-26. [CrossRef] [PubMed] 
143. Berkers, J.; Govaere, O.; Wolter, P.; Beuselinck, B.; Schöffski, P.; Van Kempen, L.C.; Albersen, M.; Oord, J.V.D.; Roskams, T.; Swinnen, J.; et al. A Possible Role for MicroRNA-141 Down-Regulation in Sunitinib Resistant Metastatic Clear Cell Renal Cell Carcinoma Through Induction of Epithelial-to-Mesenchymal Transition and Hypoxia Resistance. J. Urol. 2013, 189, 1930-1938. [CrossRef] [PubMed]

144. Merhautová, J.; Hezova, R.; Poprach, A.; Kovarikova, A.; Radova, L.; Svoboda, M.; Vyzula, R.; Demlova, R.; Slaby, O. miR-155 and miR-484 Are Associated with Time to Progression in Metastatic Renal Cell Carcinoma Treated with Sunitinib. BioMed Res. Int. 2015, 2015, 1-5. [CrossRef] [PubMed]

145. Go, H.; Kang, M.J.; Kim, P.-J.; Lee, J.-L.; Park, J.Y.; Park, J.-M.; Ro, J.Y.; Cho, Y.M. Development of Response Classifier for Vascular Endothelial Growth Factor Receptor (VEGFR)-Tyrosine Kinase Inhibitor (TKI) in Metastatic Renal Cell Carcinoma. Pathol. Oncol. Res. 2017, 25, 51-58. [CrossRef]

146. Gámez-Pozo, A.; Antón-Aparicio, L.M.; Bayona, C.; Borrega, P.; Sancho, M.I.G.; García-Domínguez, R.; De Portugal, T.; Ramos-Vázquez, M.; Pérez-Carrión, R.; Bolós, M.V.; et al. MicroRNA Expression Profiling of Peripheral Blood Samples Predicts Resistance to First-line Sunitinib in Advanced Renal Cell Carcinoma Patients. Neoplasia 2012, 14, 1144-1152. [CrossRef]

147. Chen, B.; Duan, L.; Yin, G.; Tan, J.; Jiang, X. miR-381, a novel intrinsic WEE1 inhibitor, sensitizes renal cancer cells to 5-FU by up-regulation of Cdc2 activities in 786-O. J. Chemother. 2013, 25, 229-238. [CrossRef]

148. Prior, C.; Perez-Gracia, J.L.; García-Donás, J.; Rodriguez-Antona, C.; Guruceaga, E.; Esteban, E.; Suárez, C.; Castellano, D.; Del Alba, A.G.; Lozano, M.D.; et al. Identification of Tissue microRNAs Predictive of Sunitinib Activity in Patients with Metastatic Renal Cell Carcinoma. PLoS ONE 2014, 9, e86263. [CrossRef]

149. Gao, C.; Peng, F.H.; Peng, L.K. MiR-200c sensitizes clear-cell renal cell carcinoma cells to sorafenib and imatinib by targeting heme oxygenase-1. Neoplasma 2014, 61, 680-689. [CrossRef]

150. Mu, W.; Hu, C.; Zhang, H.; Qu, Z.; Cen, J.; Qiu, Z.; Li, C.; Ren, H.; Li, Y.; He, X.; et al. miR-27b synergizes with anticancer drugs via p53 activation and CYP1B1 suppression. Cell Res. 2015, 25, 477-495. [CrossRef]

151. Zheng, B.; Zhu, H.; Gu, D.; Pan, X.; Qian, L.; Xue, B.; Yang, D.; Zhou, J.; Shan, Y. MiRNA-30a-mediated autophagy inhibition sensitizes renal cell carcinoma cells to sorafenib. Biochem. Biophys. Res. Commun. 2015, 459, 234-239. [CrossRef]

152. Chang, I.; Mitsui, Y.; Fukuhara, S.; Gill, A.; Wong, D.K.; Yamamura, S.; Shahryari, V.; Tabatabai, Z.L.; Dahiya, R.; Shin, D.M.; et al. Loss of miR-200c up-regulates CYP1B1 and confers docetaxel resistance in renal cell carcinoma. Oncotarget 2015, 6, 7774-7787. [CrossRef] [PubMed]

153. Long, Q.-Z.; Du, Y.-F.; Liu, X.-G.; Li, X.; He, D.-L. miR-124 represses FZD5 to attenuate P-glycoprotein-mediated chemo-resistance in renal cell carcinoma. Tumor Boil. 2015, 36, 7017-7026. [CrossRef] [PubMed]

154. Khella, H.W.Z.; Butz, H.; Ding, Q.; Rotondo, F.; Evans, K.R.; Kupchak, P.; Dharsee, M.; Latif, A.; Pasic, M.D.; Lianidou, E.; et al. miR-221/222 Are Involved in Response to Sunitinib Treatment in Metastatic Renal Cell Carcinoma. Mol. Ther. 2015, 23, 1748-1758. [CrossRef] [PubMed]

155. Lukamowicz-Rajska, M.; Mittmann, C.; Prummer, M.; Zhong, Q.; Bedke, J.; Hennenlotter, J.; Stenzl, A.; Mischo, A.; Bihr, S.; Schmidinger, M.; et al. MiR-99b-5p expression and response to tyrosine kinase inhibitor treatment in clear cell renal cell carcinoma patients. Oncotarget 2016, 7, 78433-78447. [CrossRef] [PubMed]

156. Pili, R.; Liu, G.; Chintala, S.; Verheul, H.; Rehman, S.; Attwood, K.; Lodge, M.A.; Wahl, R.; Martin, J.I.; Miles, K.M.; et al. Combination of the histone deacetylase inhibitor vorinostat with bevacizumab in patients with clear-cell renal cell carcinoma: A multicentre, single-arm phase I/II clinical trial. Br. J. Cancer 2017, 116, 874-883. [CrossRef] [PubMed]

157. Puente, J.; Laínez, N.; Dueñas, M.; Méndez-Vidal, M.J.; Esteban, E.; Castellano, D.; Martinez-Fernández, M.; Basterretxea, L.; Juan-Fita, M.J.; Antón, L.; et al. Novel potential predictive markers of sunitinib outcomes in long-term responders versus primary refractory patients with metastatic clear-cell renal cell carcinoma. Oncotarget 2017, 8, 30410-30421. [CrossRef]

158. Xiao, W.; Lou, N.; Ruan, H.; Bao, L.; Xiong, Z.; Yuan, C.; Tong, J.; Xu, G.; Zhou, Y.; Qu, Y.; et al. Mir-144-3p Promotes Cell Proliferation, Metastasis, Sunitinib Resistance in Clear Cell Renal Cell Carcinoma by Downregulating ARID1A. Cell. Physiol. Biochem. 2017, 43, 2420-2433. [CrossRef]

159. Sun, X.; Lou, L.; Zhong, K.; Wan, L. MicroRNA-451 regulates chemoresistance in renal cell carcinoma by targeting ATF-2 gene. Exp. Boil. Med. 2017, 242, 1299-1305. [CrossRef]

160. Kovacova, J.; Juracek, J.; Poprach, A.; Büchler, T.; Kopecký, J.; Fiala, O.; Svoboda, M.; Capoor, M.N. Candidate MicroRNA Biomarkers of Therapeutic Response to Sunitinib in Metastatic Renal Cell Carcinoma: A Validation Study in Patients with Extremely Good and Poor Response. Anticancer Res. 2018, 38, 2961-2965. [CrossRef] 
161. Kovacova, J.; Juracek, J.; Poprach, A.; Kopecky, J.; Fiala, O.; Svoboda, M.; Fabian, P.; Radova, L.; Brabec, P.; Buchler, T.; et al. MiR-376b-3p Is Associated With Long-term Response to Sunitinib in Metastatic Renal Cell Carcinoma Patients. Cancer Genom. Proteom. 2019, 16, 353-359. [CrossRef]

162. He, J.; He, J.; Min, L.; He, Y.; Guan, H.; Wang, J.; Peng, X. Extracellular vesicles transmitted miR-31-5p promotes sorafenib resistance by targeting MLH1 in renal cell carcinoma. Int. J. Cancer 2020, 146, 1052-1063. [CrossRef] [PubMed]

163. Goto, Y.; Kurozumi, A.; Nohata, N.; Kojima, S.; Matsushita, R.; Yoshino, H.; Yamazaki, K.; Ishida, Y.; Ichikawa, T.; Naya, Y.; et al. The microRNA signature of patients with sunitinib failure: Regulation of UHRF1 pathways by microRNA-101 in renal cell carcinoma. Oncotarget 2016, 7, 59070-59086. [CrossRef] [PubMed]

164. Prensner, J.; Chinnaiyan, A.M. The emergence of lncRNAs in cancer biology. Cancer Discov. 2011, 1, 391-407. [CrossRef] [PubMed]

165. Wang, C.; Wang, L.; Ding, Y.; Lu, X.; Zhang, G.; Yang, J.; Zheng, H.; Wang, H.; Jiang, Y.; Xu, L. LncRNA Structural Characteristics in Epigenetic Regulation. Int. J. Mol. Sci. 2017, 18, 2659. [CrossRef]

166. Zhao, Z.; Dammert, M.A.; Grummt, I.; Bierhoff, H. lncRNA-Induced Nucleosome Repositioning Reinforces Transcriptional Repression of rRNA Genes upon Hypotonic Stress. Cell Rep. 2016, 14, 1876-1882. [CrossRef]

167. Ma, W.; Ay, F.; Lee, C.; Gülsoy, G.; Deng, X.; Cook, S.; Hesson, J.; Cavanaugh, C.; Ware, C.B.; Krumm, A.; et al. Fine-scale chromatin interaction maps reveal the cis-regulatory landscape of human lincRNA genes. Nat. Methods 2014, 12, 71-78. [CrossRef]

168. Hansen, T.B.; Jensen, T.I.; Clausen, B.H.; Bramsen, J.B.; Finsen, B.R.; Damgaard, C.K.; Kjems, J. Natural RNA circles function as efficient microRNA sponges. Nature 2013, 495, 384-388. [CrossRef]

169. Distefano, J.K. The Emerging Role of Long Noncoding RNAs in Human Disease. Metab. Pathw. Eng. 2018, 1706, 91-110. [CrossRef]

170. Huarte, M. The emerging role of lncRNAs in cancer. Nat. Med. 2015, 21, 1253-1261. [CrossRef]

171. Song, S.; Wu, Z.; Wang, C.; Liu, B.; Ye, X.; Chen, J.; Yang, Q.; Ye, H.; Xu, B.; Wang, L. RCCRT1 Is Correlated With Prognosis and Promotes Cell Migration and Invasion in Renal Cell Carcinoma. Urology 2014, 84, 730.e1. [CrossRef]

172. Wang, Y.; Liu, J.; Bai, H.; Dang, Y.; Lv, P.; Wu, S. Long intergenic non-coding RNA 00152 promotes renal cell carcinoma progression by epigenetically suppressing P16 and negatively regulates miR-205. Am. J. Cancer Res. 2017, 7, 312-322. [PubMed]

173. Xue, D.; Wang, H.; Chen, Y.; Shen, D.; Lu, J.; Wang, M.; Zebibula, A.; Xu, L.; Wu, H.; Li, G.; et al. Circ-AKT3 inhibits clear cell renal cell carcinoma metastasis via altering miR-296-3p/E-cadherin signals. Mol. Cancer 2019, 18, 151. [CrossRef] [PubMed]

174. Mattick, J.W.; Rinn, J. Discovery and annotation of long noncoding RNAs. Nat. Struct. Mol. Boil. 2015, 22, 5-7. [CrossRef] [PubMed]

175. Thrash-Bingham, C.A.; Tartof, K.D. aHIF: A Natural Antisense Transcript Overexpressed in Human Renal Cancer and During Hypoxia. J. Natl. Cancer Inst. 1999, 91, 143-151. [CrossRef] [PubMed]

176. Bertozzi, D.; Iurlaro, R.; Sordet, O.; Marinello, J.; Zaffaroni, N.; Capranico, G. Characterization of novel antisense HIF-1 $\alpha$ transcripts in human cancers. Cell Cycle 2011, 10, 3189-3197. [CrossRef]

177. Ellinger, J.; Alam, J.; Rothenburg, J.; Deng, M.; Schmidt, D.; Syring, I.; Miersch, H.; Perner, S.; Müller, S.C. The long non-coding RNA lnc-ZNF180-2 is a prognostic biomarker in patients with clear cell renal cell carcinoma. Am. J. Cancer Res. 2015, 5, 2799-2807.

178. Ren, X.; Lan, T.; Chen, Y.; Shao, Z.; Yang, C.; Peng, J. lncRNA uc009yby.1 promotes renal cell proliferation and is associated with poor survival in patients with clear cell renal cell carcinomas. Oncol. Lett. 2016, 12, 1929-1934. [CrossRef]

179. Qin, C.; Han, Z.; Qian, J.; Bao, M.; Li, P.; Ju, X.; Zhang, S.; Zhang, L.; Li, S.; Cao, Q.; et al. Expression Pattern of Long Non-Coding RNAs in Renal Cell Carcinoma Revealed by Microarray. PLoS ONE 2014, 9, e99372. [CrossRef]

180. Blondeau, J.J.; Deng, M.; Syring, I.; Schrödter, S.; Schmidt, D.; Perner, S.; Müller, S.C.; Ellinger, J. Identification of novel long non-coding RNAs in clear cell renal cell carcinoma. Clin. Epigenetics 2015, 7, 10. [CrossRef]

181. Liu, Z.; Zhang, C.; Xia, S.-Y.; Xiu, Y.-C.; Yan, H.-Y. Downregulation of long non-coding RNA TRIM52-AS1 functions as a tumor suppressor in renal cell carcinoma. Mol. Med. Rep. 2016, 13, 3206-3212. [CrossRef]

182. Li, Y.; Li, Y.; Chen, D.; Yu, Z.; Ni, L.; Mao, X.; Gui, Y.; Lai, Y.; Wang, T.; Jin, L.; et al. Identification of long-non coding RNA UCA1 as an oncogene in renal cell carcinoma. Mol. Med. Rep. 2016, 13, 3326-3334. [CrossRef] [PubMed] 
183. Wu, Y.; Wang, Y.-Q.; Weng, W.-W.; Zhang, Q.-Y.; Yang, X.-Q.; Gan, H.-L.; Yang, Y.-S.; Zhang, P.-P.; Sun, M.-H.; $\mathrm{Xu}, \mathrm{M}$.-D.; et al. A serum-circulating long noncoding RNA signature can discriminate between patients with clear cell renal cell carcinoma and healthy controls. Oncogenesis 2016, 5, e192. [CrossRef] [PubMed]

184. He, Z.-H.; Qin, X.-H.; Zhang, X.-L.; Yi, J.-W.; Han, J.-Y. Long noncoding RNA GIHCG is a potential diagnostic and prognostic biomarker and therapeutic target for renal cell carcinoma. Eur. Rev. Med. Pharmacol. Sci. 2018, 22, 46-54. [PubMed]

185. Qu, L.; Wu, Z.; Li, Y.; Xu, Z.; Liu, B.; Liu, F.; Bao, Y.; Wu, D.; Liu, J.; Wang, A.; et al. A feed-forward loop between lncARSR and YAP activity promotes expansion of renal tumour-initiating cells. Nat. Commun. 2016, 7, 12692. [CrossRef]

186. Bao, X.; Duan, J.; Yan, Y.; Ma, X.; Zhang, Y.; Wang, H.; Ni, D.; Wu, S.; Peng, C.; Fan, Y.; et al. Upregulation of long noncoding RNA PVT1 predicts unfavorable prognosis in patients with clear cell renal cell carcinoma. Cancer Biomark. 2017, 21, 55-63. [CrossRef] [PubMed]

187. Wang, A.; Bao, Y.; Wu, Z.; Zhao, T.; Wang, D.; Shi, J.; Liu, B.; Sun, S.; Yang, F.; Wang, L.; et al. Long noncoding RNA EGFR-AS1 promotes cell growth and metastasis via affecting HuR mediated mRNA stability of EGFR in renal cancer. Cell Death Dis. 2019, 10, 1-14. [CrossRef]

188. Yao, J.; Chen, Y.; Wang, Y.; Liu, S.; Yuan, X.; Pan, F.; Geng, P. Decreased expression of a novel lncRNA CADM1-AS1 is associated with poor prognosis in patients with clear cell renal cell carcinomas. Int. J. Clin. Exp. Pathol. 2014, 7, 2758-2767.

189. Zhang, H.-M.; Yang, F.-Q.; Yan, Y.; Che, J.-P.; Zheng, J.-H. High expression of long non-coding RNA SPRY4-IT1 predicts poor prognosis of clear cell renal cell carcinoma. Int. J. Clin. Exp. Pathol. 2014, 7, 5801-5809.

190. Xue, S.; Li, Q.-W.; Che, J.-P.; Guo, Y.; Yang, F.-Q.; Zheng, J.-H. Decreased expression of long non-coding RNA NBAT-1 is associated with poor prognosis in patients with clear cell renal cell carcinoma. Int. J. Clin. Exp. Pathol. 2015, 8, 3765-3774.

191. Zhang, H.-M.; Yang, F.-Q.; Chen, S.-J.; Che, J.; Zheng, J.-H. Upregulation of long non-coding RNA MALAT1 correlates with tumor progression and poor prognosis in clear cell renal cell carcinoma. Tumor Boil. 2014, 36, 2947-2955. [CrossRef]

192. Wang, L.; Cai, Y.; Zhao, X.; Jia, X.; Zhang, J.; Liu, J.; Zhen, H.; Wang, T.; Tang, X.; Liu, Y.; et al. Down-regulated long non-coding RNA H19 inhibits carcinogenesis of renal cell carcinoma. Neoplasma 2015, 62, 412-418. [CrossRef]

193. Wu, Y.; Tan, C.; Weng, W.-W.; Deng, Y.; Zhang, Q.-Y.; Yang, X.-Q.; Gan, H.-L.; Wang, T.; Zhang, P.-P.; Xu, M.-D.; et al. Long non-coding RNA Linc00152 is a positive prognostic factor for and demonstrates malignant biological behavior in clear cell renal cell carcinoma. Am. J. Cancer Res. 2016, 6, 285-299. [PubMed]

194. Wang, P.-Q.; Wu, Y.-X.; Zhong, X.-D.; Liu, B.; Qiao, G. Prognostic significance of overexpressed long non-coding RNA TUG1 in patients with clear cell renal cell carcinoma. Eur. Rev. Med. Pharmacol. Sci. 2017, 21, 82-86. [PubMed]

195. Su, H.; Sun, T.; Wang, H.; Shi, G.; Zhang, H.; Sun, F.-K.; Ye, D. Decreased TCL6 expression is associated with poor prognosis in patients with clear cell renal cell carcinoma. Oncotarget 2016, 8, 5789-5799. [CrossRef] [PubMed]

196. Gong, X.; Siprashvili, Z.; Eminaga, O.; Shen, Z.; Sato, Y.; Kume, H.; Homma, Y.; Ogawa, S.; Khavari, P.A.; Pollack, J.R.; et al. Novel lincRNA SLINKY is a prognostic biomarker in kidney cancer. Oncotarget 2017, 8, 18657-18669. [CrossRef] [PubMed]

197. Xu, Y.; Tong, Y.; Zhu, J.; Lei, Z.; Wan, L.; Zhu, X.; Ye, F.; Xie, L. An increase in long non-coding RNA PANDAR is associated with poor prognosis in clear cell renal cell carcinoma. BMC Cancer 2017, 17, 373. [CrossRef]

198. Li, J.-K.; Chen, C.; Liu, J.-Y.; Shi, J.-Z.; Liu, S.-P.; Liu, B.; Wu, D.-S.; Fang, Z.-Y.; Bao, Y.; Jiang, M.-M.; et al. Long noncoding RNA MRCCAT1 promotes metastasis of clear cell renal cell carcinoma via inhibiting NPR3 and activating p38-MAPK signaling. Mol. Cancer 2017, 16, 111. [CrossRef]

199. Yang, T.; Zhou, H.; Liu, P.; Yan, L.; Yao, W.; Chen, K.; Zeng, J.; Li, H.; Hu, J.; Xu, H.; et al. IncRNA PVT1 and its splicing variant function as competing endogenous RNA to regulate clear cell renal cell carcinoma progression. Oncotarget 2017, 8, 85353-85367. [CrossRef]

200. Flippot, R.; Mouawad, R.; Spano, J.-P.; Rouprêt, M.; Compérat, E.; Bitker, M.-O.; Parra, J.; Vaessen, C.; Allanic, F.; Manach, Q.; et al. Expression of long non-coding RNA MFI2-AS1 is a strong predictor of recurrence in sporadic localized clear-cell renal cell carcinoma. Sci. Rep. 2017, 7, 1-9. [CrossRef] 
201. Su, H.; Wang, H.; Shi, G.-H.; Zhang, H.; Sun, F.; Ye, D. Downregulation of long non-coding RNA ENSG00000241684 is associated with poor prognosis in advanced clear cell renal cell carcinoma. Eur. J. Surg. Oncol. 2018, 44, 840-846. [CrossRef]

202. Wang, L.-N.; Zhu, X.-Q.; Song, X.-S.; Xu, Y. Long noncoding RNA lung cancer associated transcript 1 promotes proliferation and invasion of clear cell renal cell carcinoma cells by negatively regulating miR-495-3p. J. Cell. Biochem. 2018, 119, 7599-7609. [CrossRef]

203. Ding, C.; Han, F.; Xiang, H.; Xia, X.; Wang, Y.; Dou, M.; Zheng, J.; Li, Y.; Xue, W.; Ding, X.; et al. LncRNA CRNDE is a biomarker for clinical progression and poor prognosis in clear cell renal cell carcinoma. J. Cell. Biochem. 2018, 119, 10406-10414. [CrossRef] [PubMed]

204. Qu, L.; Ding, J.; Chen, C.; Wu, Z.; Liu, B.; Gao, Y.; Chen, W.; Liu, F.; Sun, W.; Li, X.-F.; et al. Exosome-Transmitted lncARSR Promotes Sunitinib Resistance in Renal Cancer by Acting as a Competing Endogenous RNA. Cancer Cell 2016, 29, 653-668. [CrossRef] [PubMed]

205. Xu, Z.; Yang, F.; Wei, D.; Liu, B.; Chen, C.; Bao, Y.; Wu, Z.; Wu, D.; Tan, H.; Li, J.; et al. Long noncoding RNA-SRLR elicits intrinsic sorafenib resistance via evoking IL-6/STAT3 axis in renal cell carcinoma. Oncogene 2017, 36, 1965-1977. [CrossRef] [PubMed]

206. Zhai, W.; Sun, Y.; Guo, C.; Hu, G.; Wang, M.; Zheng, J.; Lin, W.; Huang, Q.; Li, G.; Zheng, J.; et al. LncRNA-SARCC suppresses renal cell carcinoma (RCC) progression via altering the androgen receptor(AR)/miRNA-143-3p signals. Cell Death Differ. 2017, 24, 1502-1517. [CrossRef] [PubMed]

207. Liu, L.; Pang, X.; Shang, W.; Xie, H.; Feng, Y.; Feng, G. Long non-coding RNA GAS5 sensitizes renal cell carcinoma to sorafenib via miR-21/SOX5 pathway. Cell Cycle 2019, 18, 257-263. [CrossRef] [PubMed]

(C) 2020 by the authors. Licensee MDPI, Basel, Switzerland. This article is an open access article distributed under the terms and conditions of the Creative Commons Attribution (CC BY) license (http://creativecommons.org/licenses/by/4.0/). 